\title{
1 Reduced growth sensitivity to climate in bark-beetle 2 infested Aleppo pines: connecting climatic and biotic 3 drivers of forest dieback
}

4

5 Gabriel Sangüesa-Barreda ${ }^{1}$, Juan Carlos Linares ${ }^{2}$ and J. Julio Camarero ${ }^{1}$

$6{ }^{1}$ Instituto Pirenaico de Ecología (IPE-CSIC). Avda. Montañana 1005, Apdo. 202, 50192

7 Zaragoza, Spain.

$8 \quad{ }^{2}$ Departamento de Sistemas Físicos, Químicos y Naturales, Universidad Pablo de Olavide. Ctra.

$9 \quad$ Utrera km. 1, 41002 Sevilla, Spain.

10

11 *Corresponding author:

12 Gabriel Sangüesa-Barreda

13 Instituto Pirenaico de Ecología (IPE-CSIC)

14 Avenida Montañana 1005, Zaragoza E-50192, Spain.

15 E-mail: gsanguesa@ipe.csic.es

16 Tel. 0034-976-716031, Fax: 0034-976-716019

17 


\section{Abstract}

Drought and bark-beetle infestation are major and often interconnected drivers of forest dieback and tree death. These two stressors may interact and accelerate forest mortality, since warmer and drier conditions boost beetle attacks and reduce tree growth. However, the way in which drought and bark-beetle infestation interact and affect declining or dying trees is still poorly understood. To disentangle the long-term interaction between the two stressors, we quantified radial growth (basal area increment), resin production, mortality and intrinsic water-use efficiency (iWUE) inferred from wood-carbon isotope discrimination. We compared trees infested and recently killed by two abundant bark beetle species (Orthotomicus erosus and Tomicus piniperda) with non-infested living trees in a drought-prone Aleppo pine plantation. Growth and iWUE showed similar values in infested and non-infested trees. Since barkbeetle-infested trees did not grow less than non-infested trees, our results did not support the hypothesis of higher costs of resin production at the expense of stem-wood formation. Radial growth was enhanced by cool and wet winter conditions prior to the growing season. However, infested trees showed lower growth responsiveness than did non-infested trees with respect to this climatic driver of growth. Infested trees also showed a lower resin-duct production two years prior to death than non-infested trees. The growth responsiveness to climate should be characterized in bark-beetle-infested trees, since a weak correlation between climate and growth can be regarded as a predisposing factor of infestation-induced tree death. Such reduced responsiveness to climate stress could be linked to the tree vulnerability to beetle attacks in drought-prone forests.

Key words: drought stress; bark beetles; dendroecology; carbon isotopes; Pinus halepensis. 
- Aleppo pine mortality increases after severe droughts.

- Droughts and bark-beetle infestation trigger tree death.

- Beetle-infested trees produce less resin ducts two years prior to death.

- Beetle infestation does not depend on tree growth and water-use efficiency.

50

- Beetle-infested trees show reduced growth sensitivity to climate. 


\section{Introduction}

Drought frequency, intensity, and duration have increased in many semi-arid areas during the past fifty years (IPCC, 2014). Such aridification trends may trigger recurrent forest dieback and widespread tree-mortality events (Allen et al., 2010). Warmer conditions and extreme droughts have been related to cumulative stress in trees (e.g. cumulative hydraulic failure) causing growth decline, vigor loss, and tree death (Camarero et al., 2015). Nonetheless, rising temperatures could also alter tree-insect interactions, making stressed trees more vulnerable to insect infestation, thereby increasing the extent and intensity of insect-attack damage (Bale et al., 2002; Bentz et al., 2010; Carnicer et al., 2011; Krams et al., 2012). For instance, tree-ring records have revealed that drought stress reduces tree resistance to bark-beetle infestation in some conifer species (Berg et al., 2006). Moreover, different mortality events of conifer species, usually pines, have been related to bark-beetle attacks in drought-prone areas (Krams et al., 2012; Negrón et al., 2009; Wermelinger et al., 2008). Therefore, combined drought and heat stress presumably act as inciting factors (sensu Manion, 1991) by weakening host trees and exacerbating damage due to subsequent biotic stressors, such as bark-beetle infestations (Gaylord et al., 2013).

Drought and heat stress are assumed to cause forest dieback through two physiological mechanisms, which are probably related, namely hydraulic failure and carbon starvation (McDowell et al., 2008, 2011). A reduction in photosynthesis, hydraulic conductivity, and wood production could reduce tree resistance to bark-beetle attacks by altering the tree's secondary metabolism and reducing the production of active defenses, such as resins, which are the main resistance factor to prevent barkbeetle infestation (Ferrenberg et al., 2014; Netherer et al., 2015). In addition, drought stress may alter the biochemical composition of tree tissues, making stressed trees more attractive to bark beetles (Mattson and Haack, 1987). Previous studies have quantified the likelihood of bark-beetle infestation in some species at different spatial and temporal scales (Negrón et al., 2009; Kane and Kolb, 2010). Nevertheless, there are still many research gaps regarding the patterns and mechanisms underlying tree susceptibility or predisposition to insect infestation after droughts at the tree level (Raffa et al., 2008). These questions are relevant, since climate-tree-insect relationships affect the global carbon cycle, alter atmosphere-climate-forest feedback, and influence forest dynamics (Edburg et al., 2012; McDowell et al., 2011; Reed et al., 2014). For instance, recent studies show that forests severely disturbed by bark beetle outbreaks become large 
carbon sources (Hansen et al., 2015; Kurz et al., 2008). In addition, an increasing recurrence of insect outbreaks could also alter the way in which forests provide ecosystem services from aesthetic concerns to carbon and water regulation (Ayres and Lombardero, 2000).

Furthermore, climate warming could also directly determine the development and survival of insects, due to their physiological sensitivity to temperature (Hicke et al., 2006; Logan et al., 2003), or indirectly through a mismatch of the tree performance (e.g. growth, resin production) and subsequent insect dynamics (Ayres and Lombardero, 2000; Bentz et al., 2010). In summary, increasing warming and drought stress could lead to a vigor loss of infested trees by weakening tree defenses, increasing insect reproduction, and then facilitating the development of outbreaks and ultimately causing tree death (Krams et al., 2012; Loehle, 1988).

In this study, we focus on forest dieback, here characterized by growth decline and rising mortality rates of planted Aleppo pines. These trees grow under semi-arid conditions and have been recently infested by two bark beetle species with different dynamics (Tomicus piniperda, a primary beetle species, and Orthotomicus erosus, a secondary beetle species). Bark beetles are highly relevant for the forestry sector in Europe, where the estimated average wood volume lost to their infestations was about 2.9 million $\mathrm{m}^{3}$ per year in the last half of the 20th century (Schelhaas et al., 2003). While the decline model of Manion (1991) considers bark beetles to be a contributing factor of dieback, acting mainly in the final stages of tree death, here we extend this model in order to test whether drought-stressed trees are particularly vulnerable (predisposed) to bark-beetle infestations. We study Aleppo pine plantations experiencing recent dieback because plantations are structurally and genetically less heterogeneous than natural stands, and they are subjected to more homogeneous site conditions and fewer disturbances than comparable unmanaged forests (SánchezSalguero et al., 2012). Here we evaluate the interactions between drought stress and bark-beetle infestation and how they affect radial growth, water-use efficiency (iWUE) and mortality in Aleppo pine, which is a species well adapted to seasonal drought (Ne'eman and Trabaud, 2000). We also explore whether there are specific traits (diameter, growth rate, growth responsiveness to climate, resin production, iWUE) that predispose trees to bark-beetle infestations.

\section{Material and Methods}


121 The Aleppo pine (Pinus halepensis Mill.), a drought-tolerant evergreen conifer species, is widely distributed in areas subjected to seasonal water deficit, mainly low-elevation sites under Mediterranean and semi-arid conditions, across the Western Mediterranean Basin (Ne'eman and Trabaud, 2000). This species has been widely planted in land restoration for forest productivity at xeric sites as a fast-growing pioneer conifer able to rapidly regenerate after fires due to its precocity and abundant seed production (Maestre and Cortina, 2004). Aleppo pine produces abundant resin ducts and it is able to show high radial-growth rates, irrespective of the cone crop amount, in response to wet conditions in winter to spring (Alfaro-Sánchez et al., 2015).

The study site is an almost flat area covered by planted Aleppo pines occupying ca. 400 ha near the city of Zaragoza (north-eastern Spain) at 340 m.a.s.l. (Supporting Information, Fig. S1). The density and basal area range between 162 and 542 stems ha $^{-1}$, and 4.12 and $20.82 \mathrm{~m}^{2} \mathrm{ha}^{-1}$, respectively. The understory vegetation is dominated by shrubs (Helianthemum sp., Genistascorpius, Thymus vulgaris, and Rosmarinus officinalis). The soils are cambisols poorly developed over gypsum outcrops.

Tomicus piniperda L. (the common pine-shoot beetle) is a primary beetle species considered to be one of the most important bark beetles in Europe, causing an estimated 20-45\% timber losses (Langström and Hellqvist, 1991, 1993; Poland et al., 2003). Disturbances such as forest fires, extreme droughts or windstorms can create favorable conditions for breeding. When these disturbance sites accumulate large populations of beetles, living trees or weakened trees are attacked (Martikainen et al., 2006; Morgan et al., 2004). Contrastingly, Orthotomicus erosus (Woll.) (Mediterranean pine-engraver beetle) is considered a secondary pest infesting recently fallen and already stressed trees and coexisting with other bark beetle species (Haack, 2004; Morgan et al., 2004).

\subsection{Climate data}

147 According to data from the nearby Zaragoza-airport meteorological station $\left(41^{\circ} 39^{\prime} 38^{\prime \prime}\right.$

$\left.148 \mathrm{~N}, 1^{\circ} 0^{\prime} 15^{\prime}, \mathrm{W}, 263 \mathrm{~m}\right)$, located at $12 \mathrm{~km}$ from the study site, the climate of the study area is Mediterranean of semi-arid type (Supporting Information, Fig. S2). During the 1950-2012 period, the mean annual temperature was $14.8^{\circ} \mathrm{C}$ (the coldest and warmest months were January and July, respectively) and the total annual precipitation was 325 $\mathrm{mm}$ (the wettest and driest months were May and July, respectively). To differentiate two climatically different sub-periods with wet (1971-1990) and dry (1991-2010) 
conditions, we estimated the potential evapotranspiration (PET) using monthly values of mean temperature, daily temperature range, and solar radiation following the Hargreaves-Samani method (Hargreaves and Samani, 1982). Then, we calculated the water balance as the difference between precipitation and PET (P-PET). We also calculated the cumulative water deficit from January through July as the sum of the monthly water-balance values from January to July since Aleppo pine has most of its radial stem growth during that period in the study area (Camarero et al., 2010).

\subsection{Field sampling and dendrochronological methods}

Sampling was conducted in winter 2011-2012. Sampled trees were randomly distributed across the plantation and field sampling followed standard dendrochronological methods (Fritts, 2001). In the case of non-infested trees, two 5-mm-wide cores were taken at $1.3 \mathrm{~m}$ using a Pressler increment borer. Most dead Aleppo pines were recently infested by Tomicus or Orthotomicus (see Table 1). We identified the bark beetle species by the form and size of the galleries excavated in the bark or engraved in the sapwood (Muñoz et al., 2011). We took slices from the two types of infested trees.

The collected wood samples were air-dried and polished with a series of successively finer sand-paper grits until rings were clearly visible. Tree rings were measured to the nearest $0.01 \mathrm{~mm}$ using a binocular scope and a LINTAB measuring device (Rinntech, Heidelberg, Germany). Cross-dating of the tree rings was checked using the program COFECHA (Holmes, 1983). Tree age at $1.3 \mathrm{~m}$ was estimated by counting rings along wood sections or in the oldest core, fitting a geometric pith locator to the innermost rings to estimate the distance to the theoretical pith.

We transformed tree-ring width into basal area increment (BAI), which is a more biologically meaningful descriptor of growth trends than tree-ring width (Biondi and Qeadan, 2008). The BAI was calculated from tree-ring widths as the difference between consecutive cross-sectional basal areas (BA) estimated for years $t+1$ and $t$ as:

$$
B A I_{t+1}=B A_{t+1}-B A_{t}=\pi\left(\left(C L_{t}+T R W_{t+1}\right)^{2}-\left(C L_{t}\right)^{2}\right)
$$

where $C L$ is the core length and $T R W$ is the tree-ring width corresponding to tree rings formed in years $t+1$ and $t$.

To quantify how growth responded to year-to-year climate variability the mean BAI series were related to monthly climatic variables (mean minimum and maximum temperatures, precipitation and water balance) using Pearson correlation coefficients 
and considering the 1973-2012 period when replication was the highest. To consider the year-to-year dependence of BAI in these analyses, we also calculated the first-order temporal autocorrelation of this variable.

Finally, we divided the study period of BAI analyses into two contrasting subperiods characterized by predominantly wet (1971-1990) and dry (1991-2010) conditions (Supporting Information, Fig. S2). Then, we selected the climatic variables most strongly related to BAI (January minimum temperatures, July maximum temperatures and January-to-July cumulative water balance) to analyze the growth sensitivity to climate.

\subsection{Tree mortality data}

The number of dead trees across the entire plantation was annually recorded from 1992 up to 2013 by the "Parks and Gardens Service" of the Zaragoza city hall (Supporting Information, Fig. S1). They carried out periodic field visits to assess the state of forest health and determine the number of dead trees each year. Since mortality data taken from 2005 to 2009 covered half of the study area due to changes in the service staff, we multiplied the annual mortality data of that period by two. However, for caution, we did not consider this period when describing the main results concerning tree mortality.

\subsection{Resin-duct production and bark galleries}

Oleoresin production is an important defense in tree resistance to bark beetles attacks (Kane and Kolb, 2010). Thus, we compared the resin-duct development of dead trees attacked by bark beetles of the two species vs. living non-infested trees. In this way, we measured resin-duct production (no. ducts year ${ }^{-1}$ ) and resin-duct density (no. $\mathrm{mm}^{-2}$ ) in two radii along cores taken from 10 trees of each tree type. Resin-duct density was estimated along a 4-mm-wide section of the cores and for the 1970-2011 period by inspecting carefully sanded and cross-dated samples using a binocular microscope (Ferrenberg et al., 2014; Kane and Kolb, 2010; Wimmer and Grabner, 1997). Resinduct production was measured as the number of resin ducts formed per annual ring. Moreover, we calculated resin-duct density as the number of resin ducts present per unit area of wood. Finally, we removed part of the growth influence on the resin-duct production by expressing the results as standardized values of resin-duct production in relation to standardized tree-ring widths. 
Additionally, we counted the number of galleries engraved in the outer sapwood of the wood disks corresponding to dead trees infested by bark beetles. The number of galleries was expressed as related to stem area (No. galleries $\mathrm{mm}^{-2}$ ). Finally, we compared the gallery densities between trees infested by the two bark-beetle species.

\subsection{Water-use efficiency inferred from carbon isotope discrimination}

To compare the changes in intrinsic water-use efficiency (iWUE) of dead trees infested by the two bark beetles species and living non-infested trees, we measured ${ }^{13} \mathrm{C}^{12} \mathrm{C}$ isotope ratios in the stem wood. We sampled 15 trees randomly selected ( 5 trees per tree type) by taking wood disks or cores. The sampled trees were dominant and of comparable diameter at breast height (dbh) and age (dbh, dead Orthotomicus-infested trees mean $\pm \mathrm{SE}=14.2 \pm 0.8 \mathrm{~cm}$, dead Tomicus-infested trees mean $\pm \mathrm{SE}=13.7 \pm 0.8$ $\mathrm{cm}$, non-infested trees mean $\pm \mathrm{SE}=1.5 \pm 0.4 \mathrm{~cm}$; age: dead Orthotomicus -infested trees mean $\pm \mathrm{SE}=56 \pm 2$ years, dead Tomicus-infested trees mean $\pm \mathrm{SE}=56 \pm 2$ years, noninfested trees mean $\pm \mathrm{SE}=49 \pm 5$ years; see also Table 1). Disks and cores were visually cross-dated and tree-ring width and BAI were calculated as explained above. Wood segments containing 10 contiguous annual tree rings corresponding to the two climatically different sub-periods (1970-1991 and 1991-2010) were carefully separated with a razor blade under a binocular microscope. We analyzed segments instead of individual tree rings to account for a large enough number of trees while maintaining low-frequency temporal variability.

Wood samples were carefully homogenized and milled using an ultra-centrifugation mill (Retsch ZM1, mesh size of $0.5 \mathrm{~mm}$ ). An aliquot of 0.5-0.7 mg of each wood sample was weighed on a balance (Mettler Toledo AX205) and placed into a tin capsule for isotopic analyses. Cellulose was not extracted, since both whole wood and cellulose isotope time-series showed similar long-term trends related to atmospheric $\mathrm{CO}_{2}$ concentration and climate (Saurer et al. 2004). Furthermore, a carryover effect from year to year can be regarded as negligible, given that we analyzed 10-ring wood segments. The isotope ratio ${ }^{13} \mathrm{C} /{ }^{12} \mathrm{C}\left(\delta^{13} \mathrm{C}\right)$ was determined on an isotope ratio mass spectrometer (ThermoFinnigan MAT 251) at the Stable Isotope Facility (University of California, Davis, USA). The results were expressed as relative differences in the ${ }^{13} \mathrm{C} /{ }^{12} \mathrm{C}$ ratio of tree material with respect to the Vienna Pee-Dee Belemnite (V-PDB) standard. Two analytical standards were included for analysis after every 10 wood samples: cellulose $\left(\delta^{13} \mathrm{C}=-24.72 \%\right)$ and phthalic acid $\left(\delta^{13} \mathrm{C}=-30.63 \%\right)$. The repeated 
analysis of these two internal standards yielded a standard deviation lower than $0.1 \%$ o and the accuracy of analyses was $0.07 \%$. The estimated precision of the measurements was $\pm 0.1 \%$.

Isotopic discrimination between the carbon of atmospheric $\mathrm{CO}_{2}$ and wood carbon $(\Delta$; see Farquhar and Richards, 1984) was defined as:

$$
\Delta=\left(\delta^{13} \mathrm{C}_{\mathrm{atm}}-\delta^{13} \mathrm{C}_{\text {plant }}\right) /\left(1+\delta^{13} \mathrm{C}_{\text {plant }} / 1000\right)
$$

where $\delta^{13} \mathrm{C}_{\text {atm }}$ and $\delta^{13} \mathrm{C}_{\text {plant }}$ are the isotope ratios of carbon $\left({ }^{13} \mathrm{C} /{ }^{12} \mathrm{C}\right)$ in atmospheric $\mathrm{CO}_{2}$ and tree-ring wood, respectively, expressed in parts per thousand (\%o) relative to the standard V-PDB; $\Delta$ is linearly related to the ratio of intercellular $\left(c_{i}\right)$ to atmospheric $\left(c_{a}\right)$ $\mathrm{CO}_{2}$ mole fractions, by (see Farquhar et al., 1982):

$$
\Delta=a+(b-a) c_{i} / c_{a}
$$

where $a$ is the fractionation during $\mathrm{CO}_{2}$ diffusion through the stomata (4.4\%o), and $b$ is the fractionation associated with reactions by Rubisco and PEP carboxylase (27\%; Farquhar and Richards, 1984). The values for variables $c_{a}$ and $\delta^{13} \mathrm{C}_{\mathrm{atm}}$ were obtained from published data ( McCarroll and Loader, 2004).

The $c_{i} / c_{a}$ ratio reflects the balance between net assimilation $(A)$ and stomatal conductance for $\mathrm{CO}_{2}\left(g_{\mathrm{c}}\right)$ according to Fick's law: $A=g_{\mathrm{c}}\left(c_{a}-c_{i}\right)$. Stomatal conductances for $\mathrm{CO}_{2}$ and water vapor $\left(g_{\mathrm{w}}\right)$ are related by a constant factor $\left(g_{\mathrm{w}}=1.6 g_{\mathrm{c}}\right)$, and hence these last two variables allow linking the leaf-gas exchange of carbon and water. The linear relationship between $c_{i} / c_{a}$ and $\Delta$ may be used to calculate the intrinsic water-use efficiency (iWUE), defined as the ratio of net assimilation to stomatal conductance $\left(A / g_{w}\right)$, which is calculated as follows:

$$
\mathrm{iWUE}=\left(c_{a} / 1.6\right)[(b-\Delta) /(b-a)]
$$

The iWUE ( $\mu \mathrm{mol} \mathrm{mol}{ }^{-1}$ ) inferred from $\delta^{13} \mathrm{C}$ has been widely related to trends in the internal regulation of carbon uptake and water loss in plants (see McCarroll and Loader, 2004; Robertson et al., 2011) assuming that $\Delta$ relates linearly to $c_{i} / c_{a}$. However, the iWUE should not be considered as equivalent to actual water-use efficiency, which is the ratio of assimilation (gained carbon) to transpiration (lost water) (see Seibt et al., 2008).

\section{7. $\quad$ Linear mixed-effects models of basal area increment}

To model BAI as a function of climate, linear mixed-effects models were separately fitted to BAI data of the three tree types (living non-infested trees and dead trees 
infested by Orthotomicus and Tominus) considering the 1973-2012 period. We adjusted the following linear mixed-effects model:

$$
B A I_{i}=X_{i} \beta+Z_{i} b_{i}+\varepsilon_{i}(5),
$$

where $B A I_{\mathrm{i}}$ represents the growth of tree $i, \beta$ is the vector of fixed effects (climate variables), $b_{i}$ is the vector of random effects (tree identity and age), $X_{i}$ and $Z_{i}$ are, respectively, fixed and random effects regressor matrices, and $\varepsilon_{I}$ is the within-group error vector.

We used monthly climatic variables (mean temperature, summed precipitation, and water balance) as predictors on the basis that these climatic variables influence Aleppo pine growth according to previous xylogenesis and dendroecological works in the study area (Camarero et al., 2010; Pasho et al., 2012). Residuals of the models were checked for normality, homoscedasticity, and autocorrelation. The effects of climate on BAI were tested and compared with a null model considering BAI of the previous year as a constant (see Biondi and Qeadan, 2008). We also evaluated the existence of multicollinearity among fixed effects by calculating the variance inflation factor, which was invariably lower than three, suggesting no redundancy problems among predictors (Zuur et al., 2009). The random effects and the covariance parameters were estimated using the restricted maximum likelihood method (Zuur et al., 2009). We used an information-theoretic approach for multi-model selection (see Burnham and Anderson, 2002), based on the AIC (Akaike Information Criterion) corrected for small sample sizes (AICc). To rank the fitted models, we also calculated $\Delta i$ (difference in AICc with respect to the best model) and $W i$ (relative probability that the model $i$ was the best model for the observed data). We considered models with substantial support to be those in which the $\triangle \mathrm{AIC}$, i.e. the difference of AICc between models, was less than 2 (Zuur et al., 2009). We fitted linear mixed-effects models using the nlme library of the R statistical suite version 2.14 (R Development Core Team 2015).

\section{Results}

\subsection{Characteristics of tree types}

Non-infested trees presented a higher dbh and age than dead and beetle-infested trees (Table 1). The density of bark-beetle galleries was higher in dead trees infested by Orthotomicus than in those infested by Tomicus (Table 1). The number of bark-beetle galleries was significantly related to the tree diameter in the case of trees infested by 
Tomicus (Supporting Information, Fig. S3). The number of galleries also showed a significant relationship with past and recent growth values in Orthotomicus-infested trees (Supporting Information, Fig. S4). Moreover, the number of galleries was significantly and negatively related to tree-ring carbon isotopic discrimination values (and thus tree water-use efficiency) during the wet 1971-1990 sub-period (Supporting Information, Fig. S5), but this was not the case for the dry 1991-2010 sub-period.

\subsection{Tree mortality}

The mortality data registered a marked increment in 1996 (Fig. 1A), probably associated with the previous 1994 and 1995 droughts (see Supporting Information, Fig. S2). Analogously, mortality peaked in 2004 and 2006 after dry periods or years with very negative water balances (1998-2002, 2005), and also in 2013 associated with the extremely warm and dry year of 2012. Tree mortality was positively and significantly related to the water balance of December $\left(r^{2}=0.60, P=0.003\right)$.

\subsection{Basal-area increment and intrinsic water-use efficiency.}

Growth showed similar values and year-to-year variability in dead trees infested by bark beetles or non-infested trees (Fig. 1B). We found significantly lower growth rates only during the juvenile phase (1970-1975) in the case of bark-beetle-infested trees regardless of the beetle species $(F=37.54, P<0.001)$, and a significantly higher growth rate in the case of living trees during the 2008-2012 period (Table 1). It is remarkable that the last ring formed by most dead and infested trees was 2012. BAI autocorrelation showed no significant differences between tree types, suggesting a similar structure of first-order autocorrelation for the remaining tree types. We found a significantly more negative BAI trend during the 1971-1990 sub-period in non-infested trees with respect to dead trees infested by bark beetles (Table 2). Lastly, the iWUE was similar for all tree types and both sub-periods considered (Table 2).

\subsection{Growth responses to climate in dead bark-beetle-infested and non-infested} trees.

The relationship between BAI and climatic variables showed positive significant correlations of BAI with the minimum temperature, precipitation, and water balance during the winter (December and January), and negative correlations with maximum July temperatures (Fig. 2). BAI was also enhanced by a positive water balance in April 
and July. Furthermore, we found that warmer and wetter January conditions enhanced BAI of non-infested trees more than in the case of infested trees. This difference was significant during the wet 1971-1990, when the BAI of non-infested trees was more enhanced than in infested trees from January to July overall water balance (Table 2). This stronger responsiveness of non-infested trees to water availability was also manifested in summer since BAI decreased more in response to warmer July conditions in non-infested than in bark-beetle-infested trees during the wet 1971-1990 sub-period. The strongest positive growth responses to cumulative water balance were observed in late January and mid April at 15- and 10-day-long scales, irrespective of the infestation tree type (results not presented).

The linear mixed-effects models confirmed the results of the relationships between BAI and climatic variables, showing that the most significant drivers of BAI were warm May to July maximum temperatures (May, June, and July), January to February minimum temperatures and the water balance of the previous winter (December, January) and of the current spring and summer (April, June, and July; see Table 3). Models adjusted for dead trees infested by bark beetles explained BAI better (higher Wi) than in the case of dead but non-infested trees (Table 3, see also Supporting Information, Table S1). Observed and fitted BAI values were similar suggesting a strong influence of climate as the driver of BAI (Fig. 3).

\subsection{Differences in resin-duct production}

Wider rings produced more resin ducts, since there was a significant $(P<0.001)$ positive correlation between BAI and resin-duct production in Orthotomicus- $\left(r^{2}=0.34\right)$ and Tomicus-infested trees $\left(r^{2}=0.33\right)$, and also in non-infested trees $\left(r^{2}=0.59\right.$; Fig. 4A and $5 \mathrm{~A}$ ). However, this relationship was not detected in the case of resin-duct density (Fig. 4B).

Lower resin-duct production was found in the non-infested trees with respect to dead trees infested by bark beetles independently of the sub-period considered (Table 2 , Fig. 4). Resin-duct production was higher in Tomicus-infested trees than in other tree types from 1991 onwards. However, we found no significant differences between tree types in the standardized difference between resin-duct production and tree-ring width (Fig. 5A). Moreover, the resin-duct production was lower in dead trees infested by bark beetles two years prior to their death than in non-infested trees. In general, a lower number of resin ducts was associated with dry climatic conditions and vice versa (Fig. 
5A). Furthermore, we found significantly narrower tree rings in trees infested by Orthotomicus with respect to non-infested trees in those years characterized by a moderate (2-3 resin ducts) or high ( $>6$ resin ducts) resin duct production, while noninfested trees showed wider rings (Fig. 5B). Trees infested by Tomicus showed wider tree rings in those cases where no resin duct was detected.

\section{Discussion}

Our study of the predisposing factors in Aleppo pine mortality from drought and bark beetles revealed reduced long-term growth responsiveness to climate (Fig. 2), as well as a significantly different growth trend in the wet period such as 1971-1990 (Table 2). However, we found no significant differences in growth, iWUE or resin-duct production between infested and non-infested trees (Fig. 1B and Table 2). Also, resin-duct production of infested trees declined two years prior to their death (Fig. 5A). Overall, these findings may indicate a higher risk of death due to recurrent droughts and barkbeetle infestations in trees with the following predisposing characteristics: weaker correlations between climate and growth, decline in resin-duct production two years prior to tree death, and higher growth rates during the wet 1971-1990 period. Moreover, the interaction of two stressors such as droughts and bark beetles played a decisive role in triggering high mortality rates.

The significantly reduced sensitivity observed in infested trees agrees with the trend that the growth of non-infested trees declined most in response to unfavorable climatic conditions, specifically dry previous winters. This suggests that bark-beetle-infested Aleppo pines were characterized by a weak correlation between climate and growth, but not necessarily lower growth rates than non-infested trees. We suggest that stem-wood production in infested trees could depend less on winter to spring soil-water availability than in the case of non-infested trees, albeit this was not reflected in terms of differences in iWUE. Thus, growth of non-infested trees responded more to the variability in water availability, which could affect the active production of chemical substances (e.g. monoterpenes) to defend against bark beetles, despite that this was not necessarily reflected in the formation of more resin ducts. The reduced growth sensitivity to water availability of infested trees could thus be used as a predictor in models used to forecast the probability of bark-beetle-induced tree death in Aleppo pine.

In our study trees infested by bark beetles did not grow less than non-infested trees. This finding agrees with previous studies in other pine species which reported no 
growth differences between infested and non-infested trees (Santoro et al., 2000; Kane and Kolb, 2010). Overall, we found no carbon-related trade-off between radial growth and defense production (Kane and Kolb, 2010), as predicted by plant-defense theory (Herms and Mattson, 1992). Tree growth and resin-duct production were positively related (Figs. 3A and 4). This result is consistent with other studies that have assessed the relationships between resin flow, resin-duct production, and radial growth in ponderosa pine (Gaylord et al., 2007; Kane and Kolb, 2010; McDowell et al., 2007) and also in Norway spruce (Rosner and Hannrup, 2004). This relationship could indicate similar climatic drivers between tree growth and resin-duct production since some studies suggest a strong relationship between resin-duct formation and summer temperatures during the late growing season, this explaining why resin ducts appear more frequently in the late wood (Wimmer and Grabner, 1997). Moreover, other authors indicate that tree genetics may be a more important factor than environmental conditions in controlling resin production (Rosner and Hannrup, 2004) but, in this study case, genetic variability is assumed to be low since seed sources of planted trees were homogeneous.

We also acknowledge the limitation imposed by evaluating the growth responses of planted pines to drought and bark-beetle infestations, since plantations show a restricted range in factors affecting tree growth (tree size and age, genetic variability, environmental heterogeneity) as compared with natural stands. The regular and constant tree distribution of planted pines and their relatively similar sizes and ages indicate they are subjected to similar aboveground competition intensities. In addition, the reported growth rates (1.0-2.4 $\mathrm{cm}^{2} \mathrm{yr}^{-1}$ ) were usually lower than those observed for Aleppo pines of similar age and size growing in nearby natural stands (1.5-4.0; cf. Pasho et al., 2012; Camarero et al., 2015).

The results presented confirm the major positive importance of the water balance during the winter (prior to the growing season) and the negative effect of warm summer conditions on Aleppo pine growth in semi-arid sites (Table 3, Fig. 2). These findings agree with the climatic drivers of growth inferred at inter- and intra-annual scales in nearby Aleppo pine forests subjected to drought stress (Camarero et al., 2010; De Luis et al., 2013; Pasho et al., 2012).

The observed relationship between the number of bark-beetle galleries and iWUE for the wet 1971-1990 sub-period, but not for the dry 1991-2010 sub-period, suggest a lower incidence of bark-beetle infestation in trees with higher iWUE. However, this 
result should be interpreted with caution, given that carbon isotope values were obtained for a relatively low number of trees. Nonetheless, our findings are confirmed by similar $\Delta{ }^{13} \mathrm{C}$ values obtained in semi-arid Aleppo pine forests across Spain (Ferrio et al., 2003). Moreover, there are no significant differences in iWUE among tree types, and all tree types seem to have increased their iWUE in a similar way (Table 2).

We observed a lower resin-duct production and density in non-infested trees as compared with trees infested by bark beetles (Tables 1 and 2; Figure 4). However, these differences did not appear when resin-duct production was expressed as a function of tree-ring width, since in this case resin-duct production declined in bark-beetle-infested trees two years prior to their death (Figure 4A). Other studies have reported that trees resistant to bark-beetle attacks formed more and wider resin ducts in different pine species (Kane and Kolb, 2010; Ferrenberg et al., 2014). Nonetheless, we found that the resin defense system in the non-infested trees was no better developed than in infested trees, suggesting that all trees were similarly predisposed to bark-beetle infestation in terms of wood growth and resin-duct production. However, we did not explicitly measure the amount of available chemistry defenses, i.e. monoterpene concentrations in the cambium or phloem, and these could also explain why non-infested trees are less likely to be attacked by beetles (Boone et al., 2011). In addition, defoliations simulating insect attacks triggered a decline in the hydraulic conductivity one year after the defoliations and a related decrease in carbohydrate concentrations, suggesting that both drought stress and insect attacks can reduce the carbon pools (Anderegg and Callaway, 2012). Since plant-defense mechanisms are effective when the density of bark-beetle populations is low (Boone et al., 2011), this could also explain why we found no differences between tree infestation types. The current decline in the standardized production of resin duct suggests that trees were weakened by recent bark-beetle colonizations and recurrent droughts, reducing resin-duct formation and thus resin synthesis two years before the trees stopped growing and died. It has been reported that infested Aleppo pines are more water-stressed and present more ethanol in the phloem and sapwood, indicating characteristics inherent to early detection (Kelsey et al., 2014). Further research could combine retrospective quantifications of growth and resin-duct production with a seasonal monitoring of bark-beetle population dynamics and the production of defenses in trees with varied infestation rates.

The reported Aleppo pine dieback may be described using a multi-causal mortality model of fast growth decline and vigor reduction caused by bark-beetle infestations and 
the extreme 2012 drought, which was the driest year since 1950 (see Fig S2). Moreover, it is important to highlight that the poor developed soils and the recurrent droughts could trigger a generalized loss of vigor and reduced growth rates, allowing bark beetles to infest Aleppo pines irrespective of the trees' characteristics. This proposed mechanism agrees with the increase of mortality observed in the study area after recent droughts (Fig. 1A). These patterns of related mortality events triggered by bark-beetle attacks and drought-stress increase have been detected worldwide in natural forests (Bentz et al., 2010; Berg et al., 2006; Carnicer et al., 2011; Dobbertin et al., 2007; Gaylord et al., 2013; Krams et al., 2012; Mattson and Haack, 1987; Negrón et al., 2009). Moreover, our results agree with studies in Valais (Switzerland) that found a higher colonization by bark beetles in drought-stressed trees, which in their case also presented a low crown cover (Wermelinger et al., 2008).

We assessed several factors that could predispose planted Aleppo pines to dieback and death as related to bark-beetle infestations and drought stress. However, our retrospective approach does not provide temporal evidence for the pattern and relevance of the factors involved, this likely being due to the inherent complexity of dieback processes, which include lagged driver-response relationships. First, tree responses such as growth decline or changes in iWUE lag stressors (drought, bark-beetle infestation) (Bigler and Rigling, 2013). Second, we did not have the data required to characterize the population dynamics of bark beetles as related to infestation rates, For instance, a long-term comparison of tree-mortality rates in years with high and low incidences of bark beetles could provide stronger evidence that tree mortality is related to the interactive effect of negative climate conditions and bark-beetle attacks. Lastly, it remains a challenge to disentangle the relative importance of bark-beetle infestation and drought as drivers of forest dieback and mortality if these factors act synergistically on tree vigor and death over long time scales.

Probably, warmer and drier winter conditions affecting the study area would accelerate the infestation dynamics of bark beetles but could also lead to growth decline due to rising evapotranspiration rates. Since the study plantations are scarcely managed and develop over shallow soils in a drought-prone area, we expect more frequent barkbeetle-related mortality episodes after severe droughts than in natural mixed and structurally diverse Aleppo pine stands. We suggest that the study plantations should be converted into heterogeneous or even mixed forests, including drought-adapted and beetle-resistant native tree species of the genus Juniperus (e.g. J. thurifera) and Quercus 
524 (e.g. $Q$. coccifera or $Q$. ilex), which could buffer the negative effects of bark beetle

525 infestations through increased functional diversity (Lombardero et al., 2008; Nadrowski

526 et al., 2010). Thinning and local irrigation could also promote the establishment of those

527 tree species, allowing the development of mixed plantations.

528 In conclusion, dead trees infested by bark beetles were characterized by reduced 529 growth sensitivity to climate. We detected no differences between dead trees recently 530 infested by bark beetles and living non-infested trees regarding past growth values, resin 531 production, and iWUE. Bark-beetle-infested trees rapidly died and presented a decline 532 in resin-duct production two years prior to death. Hence, bark beetles could either kill 533 trees already weakened by droughts, or directly cause fast tree death.

534

\section{Acknowledgments}

536 We sincerely thank José Bellosta and Montserrat Hernández (Zaragoza Forests and 537 Gardens service) for their advice and help in understanding the Aleppo pine dieback 538 studied. This study was supported by projects CGL2008-04847-C02-01 and CGL201153926654 (Spanish Ministry of Economy and Competitiveness). We thank the Spanish 540 Meteorological Agency for providing climate data. 
543 Alfaro-Sánchez, R., Camarero, J.J., López-Serrano, F.R., Sánchez-Salguero, R., Moya, D., De las Heras, J., 2015. Positive coupling between growth and reproduction in young post-fire Aleppo pines depends on climate and site conditions. Int. J. Wildl. Fire. doi 10.1071/WF14045.

Allen, C.D., Macalady, A.K., Chenchouni, H., Bachelet, D., McDowell, N., Vennetier, M., Kitzberger, T., Rigling, A., Breshears, D.D., Hogg, E.H. (Ted), Gonzalez, P., Fensham, R., Zhang, Z., Castro, J., Demidova, N., Lim, J.-H., Allard, G., Running,

Bentz, B.J., Régnière, J., Fettig, C.J., Hansen, E.M., Hayes, J.L., Hicke, J.A., Kelsey, R.G., Negrón, J.F., Seybold, S.J., 2010. Climate change and bark beetles of the western United States and Canada: direct and indirect effects. Bioscience 60, 602613. doi:10.1525/bio.2010.60.8.6

Berg, E.E., Henry, J.D., Fastie, C.L., De Volder, A.D., Matsuoka, S.M., 2006. Spruce beetle outbreaks on the Kenai Peninsula, Alaska, and Kluane National Park and Reserve, Yukon Territory: Relationship to summer temperatures and regional differences in disturbance regimes. For. Ecol. Manage. 227, 219-232. doi:10.1016/j.foreco.2006.02.038

Bigler, C., Rigling, A., 2013. Precision and accuracy of tree-ring-based death dates of mountain pines in the Swiss National Park. Trees 27, 1703-1712. doi:10.1007/s00468-013-0917-6 
Biondi, F., Qeadan, F., 2008. A theory-driven approach to tree-ring standardization: defining the biological trend from expected basal area increment. Tree-Ring Res. 64, 81-96.

Boone, C.K., Aukema, B.H., Bohlmann, J., Carroll, A.L., Raffa, K.F., 2011. Efficacy of tree defense physiology varies with bark beetle population density: a basis for positive feedback in eruptive species. Can. J. For. Res. 41, 1174-1188. doi:10.1139/x11-041

Burnham, K.P., Anderson, D.R., 2002. Model selection and multimodel inference, Springer-Verlag. New York.

Camarero, J.J., Gazol, A., Sangüesa-Barreda, G., Oliva, J., Vicente-Serrano, S.M., 2015. To die or not to die: early warnings of tree dieback in response to a severe drought. J. Ecol. 103, 44-57. doi:10.1111/1365-2745.12295

Camarero, J.J., Olano, J.M., Parras, A., 2010. Plastic bimodal xylogenesis in conifers from continental Mediterranean climates. New Phytol. 185, 471-480. doi:10.1111/j.1469-8137.2009.03073.x

Carnicer, J., Coll, M., Ninyerola, M., Pons, X., Sánchez, G., Peñuelas, J., 2011. Widespread crown condition decline, food web disruption, and amplified tree mortality with increased climate change-type drought. Proc. Natl. Acad. Sci. U. S. A. 108, 1474-8. doi:10.1073/pnas.1010070108

De Luis, M., Čufar, K., Di Filippo, A., Novak, K., Papadopoulos, A., Piovesan, G., Rathgeber, C.B.K., Raventós, J., Saz, M.A., Smith, K.T., 2013. Plasticity in dendroclimatic response across the distribution range of Aleppo pine (Pinus halepensis). PLoS One 8. doi:10.1371/journal.pone.0083550

Dobbertin, M., Wermelinger, B., Bigler, C., Bürgi, M., Carron, M., Forster, B., Gimmi, U., Rigling, A., 2007. Linking increasing drought stress to Scots pine mortality and bark beetle infestations. ScientificWorldJournal. 7, 231-9. doi:10.1100/tsw.2007.58

Edburg, S.L., Hicke, J. a., Brooks, P.D., Pendall, E.G., Ewers, B.E., Norton, U., Gochis, D., Gutmann, E.D., Meddens, A.J.H., 2012. Cascading impacts of bark beetlecaused tree mortality on coupled biogeophysical and biogeochemical processes. Front. Ecol. Environ. 10, 416-424. doi:10.1890/110173

Farquhar, G.D., O’Leary, H.M., Berry, J.A., 1982. On the relationship between carbon isotope discrimination and the intercellular carbon dioxide concentration in leaves. Aust. J. Plant Physiol. 9, 121-137. 
Farquhar, G.D., Richards, R.A., 1984. Isotopic composition of plant carbon correlates with water-use efficiency of wheat genotypes. Aust. J. Plant Physiol. 11, 539-552.

Ferrenberg, S., Kane, J.M., Mitton, J.B., 2014. Resin duct characteristics associated with tree resistance to bark beetles across lodgepole and limber pines. Oecologia 174, 1283-92. doi:10.1007/s00442-013-2841-2

Ferrio, J.P., Florit, A., Vega, A., Serrano, L., Voltas, J., 2003. $\Delta 13 \mathrm{C}$ and tree-ring width reflect different drought responses in Quercus ilex and Pinus halepensis. Oecologia 137, 512-518. doi:10.1007/s00442-003-1372-7

Fritts, H.C., 2001. Tree Rings and Climate. Caldwell.

Gaylord, M.L., Kolb, T.E., Pockman, W.T., Plaut, J.A., Yepez, E.A., Macalady, A.K., Pangle, R.E., Mcdowell, N.G., 2013. Drought predisposes piñon-juniper woodlands to insect attacks and mortality. New Phytol. 198, 567-578.

Gaylord, M.L., Kolb, T.E., Wallin, K.F., Wagner, M.R., 2007. Seasonal dynamics of tree growth, physiology, and resin defenses in a northern Arizona ponderosa pine forest. Can. J. For. Res. 37, 1173-1183. doi:10.1139/X06-309

Haack, R.A., 2004. Orthotomicus erosus: A new pine-infesting bark beetle in the United States. Newsletter of the Michigan Entomology Society 49, 3-4.

Hansen, E.M., Amacher, M.C., Miegroet, H. Van, Long, J.N., Ryan, M.G., 2015. Carbon dynamics in central US Rockies lodgepole pine type after mountain pine beetle outbreaks. For. Sci. 61, 1-15.

Hargreaves, G.H., Samani, Z.A., 1982. Estimating potential evapotranspiration. J. Irrig. Drain. Eng. 108, 225-230.

Herms, D.A., Mattson, W.J., 1992. The dilemma of plants: To grow or defend. Q. Rev. Biol. 67, 283. doi:10.1086/417659

Hicke, J.A., Logan, J.A., Powell, J., Ojima, D.S., 2006. Changing temperatures influence suitability for modeled mountain pine beetle (Dendroctonus ponderosae) outbreaks in the western United States. J. Geophys. Res. Biogeosci. 111, 1-12. doi:10.1029/2005JG000101

Holmes, R.L., 1983. Computer-assisted quality control in tree-ring dating and measurement. Tree-Ring Bull 43, 68-78.

IPCC, 2014. Climate Change 2014: Impacts, Adaptation, and Vulnerability. Part B: Regional Aspects. Contribution of Working Group II to the Fifth Assessment Report of the Intergovernmental Panel on Climate Change [Barros, V.R., C.B. 
Field, D.J. Dokken, M.D. Mastrandre. Cambridge University Press, Cambridge, United Kingdom and New York, NY, USA.

Kane, J.M., Kolb, T.E., 2010. Importance of resin ducts in reducing ponderosa pine mortality from bark beetle attack. Oecologia 164, 601-609. doi:10.1007/s00442010-1683-4

Kelsey, R.G., Gallego, D., Sánchez-García, F.J., Pajares, J.A., 2014. Ethanol accumulation during severe drought may signal tree vulnerability to detection and attack by bark beetles. Can. J. For. Res. 44, 554-561. doi:10.1139/cjfr-2013-0428

Krams, I., Daukšte, J., Kivleniece, I., Brūmelis, G., Cibulsskis, R., Āboliņš-Ābols, M., Rantala, M.J., Mierauskas, P., Krama, T., 2012. Drought-induced positive feedback in xylophagous insects: Easier invasion of Scots pine leading to greater investment in immunity of emerging individuals. For. Ecol. Manage. 270, 147152. doi:10.1016/j.foreco.2012.01.012

Kurz, W.A., Dymond, C.C., Stinson, G., Rampley, G.J., Neilson, E.T., Carroll, A.L., Ebata, T., Safranyik, L., 2008. Mountain pine beetle and forest carbon feedback to climate change. Nature 452, 987-90. doi:10.1038/nature06777

Langström, B., Hellqvist, C., 1991. Effects of different pruning regimes on growth and sapwood area of Scots pine. For. Ecol. Manage. 44, 239-254.

Långström, B., Hellqvist, C., 1993. Induced and spontaneous attacks by pine shoot beetles on young Scots pine trees: tree mortality and beetle performance. J. Appl. Entomol. 115, 25-36. doi:10.1111/j.1439-0418.1993.tb00360.x

Loehle, C., 1988. Tree life history strategies: the role of defenses. Can. J. For. Res. 18, 209-222.

Logan, J.A., Régnière, J., Powell, J.A., 2003. Assessing the impacts of global warming on forest pest dynamics. Front Ecol. Environ. 1, 130-137.

Lombardero, M.J., Vázquez-Mejuto, P., Ayres, M.P., 2008. Role of plant enemies in the forestry of indigenous vs. nonindigenous pines. Ecol. Appl. 18, 1171-1181. doi:10.1890/07-1048.1

Maestre, F.T., Cortina, J., 2004. Are Pinus halepensis plantations useful as a restoration tool in semiarid Mediterranean areas? For. Ecol. Manage. 198, 303-317. doi:10.1016/j.foreco.2004.05.040

Manion, P.D., 1991. Tree Disease Concepts. New York.

Martikainen, P., Kouki, J., Heikkala, O., Hyvarinen, E., Lappalainen, H., 2006. Effects of green tree retention and prescribed burning on the crown damage caused by the 

pine shoot beetles (Tomicus spp.) in pine-dominated timber harvest areas. J. Appl. Entomol. 130, 37-44. doi:10.1111/j.1439-0418.2005.01015.x

Mattson, W.J., Haack, R.A., 1987. The role of drought in outbreaks of plant-eating insects. Bioscience 37, 110-118.

McCarroll, D., Loader, N.J., 2004. Stable isotopes in tree rings. Quat. Sci. Rev. 23, 771-801. doi:10.1016/j.quascirev.2003.06.017

McDowell, N., Pockman, W.T., Allen, C.D., Breshears, D.D., Cobb, N., Kolb, T., Plaut, J., Sperry, J., West, A., Williams, D.G., Yepez, E.A., 2008. Mechanisms of plant survival and mortality during drought: Why do some plants survive while others succumb to drought? New Phytol. 178, 719-739. doi:10.1111/j.14698137.2008.02436.x

McDowell, N.G., Adams, H.D., Bailey, J.D., Kolb, T.E., 2007. The role of stand density on growth efficiency, leaf area index, and resin flow in southwestern ponderosa pine forests. Can. J. For. Res. 37, 343-355. doi:10.1139/X06-233

McDowell, N.G., Beerling, D.J., Breshears, D.D., Fisher, R.A., Raffa, K.F., Stitt, M., 2011. The interdependence of mechanisms underlying climate-driven vegetation mortality. Trends Ecol. Evol. 26, 523-32. doi:10.1016/j.tree.2011.06.003

Morgan, R., Groot, P., Smith, S., 2004. Susceptibility of pine plantations to attack by the pine shoot beetle (Tomicus piniperda) in southern Ontario. Can. J. For. Res. 34, 2528-2540. doi:10.1139/x04-135

Muñoz, C., Pérez, V., Cobos, P., Hernández, R., Sánchez, G., 2011. Sanidad Forestal. Guía en imágenes de plagas, enfermedades y otros agentes presentes en los bosques. Madrid.

Nadrowski K, Wirth C, Scherer-Lorenzen M. 2010 Is forest diversity driving ecosystem function and service? Curr. Opin. Env. Sust. 2, 75-79.

Ne'eman, G., Trabaud, L., 2000. Ecology, biogeography and management of Pinus halepensis and P. brutia forest ecosystems in the mediterranean basin. Backhuys Publishers, Leiden.

Negrón, F., Mcmillin, J.D., Anhold, J.A., Coulson, D., 2009. Bark beetle-caused mortality in a drought-affected ponderosa pine landscape in Arizona USA. For. Ecol. Manage. 257, 1353-1362. doi:10.1016/j.foreco.2008.12.002

Netherer, S., Matthews, B., Katzensteiner, K., Blackwell, E., Henschke, P., Hietz, P., Pennerstorfer, J., Rosner, S., Kikuta, S., Schume, H., Schopf, A., 2015. Do water- 

205, 1128-1141.

Pasho, E., Camarero, J.J., Vicente-Serrano, S.M., 2012. Climatic impacts and drought control of radial growth and seasonal wood formation in Pinus halepensis. Trees 26, 1875-1886. doi:10.1007/s00468-012-0756-х

Poland, M., Groot, P. De, Burket, S., Wakarchukt, D., Haack, R.A., Nott, R., Scarr, T., 2003. Development of an improved attractive lure for the pine shoot beetle, Tomicus piniperda (Coleoptera : Scolytidae). Agric. For. Entomol. 5, 293-300.

R Development Core Team., 2015. A Language and Environment for Statistical Computing. Vienna: R Foundation for Statistical Computing.

Raffa, K.F., Aukema, B.H., Bentz, B.J., Carroll, A.L., Hicke, J., Turner, M.G., Romme, W.H., 2008. Cross-scale drivers of natural disturbances prone to anthropogenic amplification: The dynamics of bark beetle eruptions. Bioscience 58, 501. doi:10.1641/B580607

Reed, D.E., Ewers, B.E., Pendall, E., 2014. Impact of mountain pine beetle induced mortality on forest carbon and water fluxes. Env. Res. Lett. 9. doi:10.1088/17489326/9/10/105004

Robertson, I., Leavitt, S., Loader, N., Buhay, W., 2011. Progress in isotope dendroclimatology. Chem. Geol. 252, 2001-2004. doi:10.1016/S00092541(08)00177-0

Rosner, S., Hannrup, B., 2004. Resin canal traits relevant for constitutive resistance of Norway spruce against bark beetles : environmental and genetic variability. For. Ecol. Manage. 200, 77-87. doi:10.1016/j.foreco.2004.06.025

Sánchez-Salguero, R., Navarro-Cerrillo, R.M., Camarero, J.J., Fernández-Cancio, A., 2012. Selective drought-induced decline of pine species in southeastern Spain. Clim. Change 113, 767-785. doi:10.1007/s10584-011-0372-6

Santoro, A.E., Lombardero, M.J., Ayres, M.P., Ruel, J.J., 2000. Interactions between fire and bark beetles in an old growth pine forest. For. Ecol. Manage.

Saurer, M., Siegwolf, R.T.W., Schweingruber, F.H., 2004. Carbon isotope discrimination indicates improving water-use efficiency of trees in northern Eurasia over the last 100 years. Glob. Chang. Biol. 10, 2109-2120. doi:10.1111/j.1365-2486.2004.00869.x 
Schelhaas, M.J., Nabuurs, G.J., Schuck, A., 2003. Natural disturbances in the European forests in the 19th and 20th centuries. Glob. Chang. Biol. 9, 1620-1633. doi:10.1046/j.1365-2486.2003.00684.x

Seibt, U., Rajabi, A., Griffiths, H., Berry, J.A., 2008. Carbon isotopes and water use efficiency: Sense and sensitivity. Oecologia 155, 441-454. doi:10.1007/s00442007-0932-7

Wermelinger, B., Rigling, A., Schneider Mathis, D., Dobbertin, M., 2008. Assessing the role of bark- and wood-boring insects in the decline of Scots pine (Pinus sylvestris) in the Swiss Rhone valley. Ecol. Entomol. 33, 239-249. doi:10.1111/j.13652311.2007.00960.x

Wimmer, R., Grabner, M., 1997. Effects of climate on vertical resin duct density and radial growth of Norway spruce (Picea abies). Trees 11, 271-276.

Zuur, A.F., Ieno, E.N., Walker, N., Saveliev, A.A., Smith, G.M., 2009. Mixed effects models and extensions in ecology with R. New York. 
Figure 1. Growth and mortality patterns. A) Number of dead trees of Aleppo pine in the study area from 1996 to 2013. The red line indicates the December water balance (PPET). B) Basal area increment (means \pm SE) of the three types of Aleppo pines (dead Orthotomicus- and Tomicus-infested trees and non-infested living trees) is shown for the 1970-2011 period. The bars indicate the sampling depth (number of trees measured).

Figure 2. Responses of basal area increment (BAI) to climate in dead Orthotomicus(O) and Tomicus-infested (T) trees and non-infested (NI) living Aleppo pine trees. BAI was related to monthly climate variables (Tmin and Tmax, mean minimum and maximum temperatures; P, precipitation; P-PET, water balance). The different dashed lines types indicate the 0.05 and 0.01 significance levels. Correlations were calculated from the previous October to the current September for the 1973-2012 period. Months prior to the year of tree-ring formation are abbreviated by lower-case letters.

Figure 3. Observed (discontinuous lines, means \pm SE) and fitted (thick lines) trends in basal area increment based on linear mixed-effects models for dead trees infested by Orthotomicus sp. (circles), or Tomicus sp. (squares) and living non-infested trees (triangles). Additionally, we show the variance of basal area increment explained by fitted models in the upper-right insets for each tree type.

Figure 4. A) Resin duct production (No. year ${ }^{-1}$ ) or B) density (No. $\mathrm{mm}^{-2}$ ) for dead trees infested by Orthotomicus. (orange circles) or by Tomicus (black squares) and living non-infested trees (green triangles).

Figure 5. A) Standardized difference between resin duct production (No year ${ }^{-1}$ ) and tree-ring width $\left(\mathrm{mm}^{-2}\right)$ for the period 1970-2011. Different symbols and colors indicate different tree types (Orthotomicus-dead trees, Tomicus-dead trees and non-infested trees). B) Relationship between the number of resin ducts (No.) and the tree-ring width (mm) for the period 1970-2011. Different colors indicate different tree types (dead Orthotomicus- and Tomicus-infested trees and non-infested trees) and different letters show significant differences $(P<0.05$; T2 Tamhane tests). 
791 Table 1. Characteristics and basal-area increment (BAI) data of the three sampled types of Aleppo pines. Different letters show significant 792 differences between tree types $(P<0.05$; T2 Tamhane tests).Values are means \pm SE.

793

\begin{tabular}{|c|c|c|c|c|c|c|}
\hline Tree type & $\begin{array}{l}\text { No. trees } \\
\text { (Radii) }\end{array}$ & $\begin{array}{c}\text { Diameter at breast } \\
\text { height }(\mathrm{cm})\end{array}$ & Age (years) & $\begin{array}{l}\text { Bark-beetle galleries } \\
\qquad\left(\text { No. } \mathrm{cm}^{-2}\right)\end{array}$ & $\begin{array}{c}\text { BAI 2008-2012 } \\
\left(\mathrm{cm}^{2}\right)\end{array}$ & $\begin{array}{l}\text { BAI first-order } \\
\text { temporal } \\
\text { autocorrelation }\end{array}$ \\
\hline Dead Orthotomicus-infested trees & $32(66)$ & $13.8 \pm 0.5 \mathrm{a}$ & $46 \pm 1 \mathrm{a}$ & $0.040 \pm 0.006 b$ & $1.58 \pm 0.28 \mathrm{a}$ & $0.40 \pm 0.03$ \\
\hline Dead Tomicus-infested trees & $29(58)$ & $14.4 \pm 0.6 \mathrm{a}$ & $51 \pm 1 b$ & $0.029 \pm 0.003 a$ & $1.52 \pm 0.28 \mathrm{a}$ & $0.37 \pm 0.03$ \\
\hline Living non-infested trees & $49(85)$ & $19.5 \pm 0.6 b$ & $55 \pm 1 \mathrm{c}$ & - & $2.36 \pm 0.25 b$ & $0.35 \pm 0.02$ \\
\hline
\end{tabular}




\begin{tabular}{|c|c|c|c|c|c|c|c|c|c|c|c|c|c|}
\hline \multirow{2}{*}{$\begin{array}{l}\text { Variable (units) } \\
\text { BAI }\left(\mathrm{cm}^{2} \text { year }^{-1}\right)\end{array}$} & \multirow{2}{*}{$\begin{array}{c}\text { Period } \\
1971-1990\end{array}$} & \multicolumn{4}{|c|}{$\begin{array}{c}\text { Dead Orthotomicus-infested } \\
\text { trees }\end{array}$} & \multicolumn{4}{|c|}{$\begin{array}{c}\text { Dead Tomicus-infested } \\
\text { trees } \\
\end{array}$} & \multicolumn{4}{|c|}{$\begin{array}{l}\text { Living non-infested } \\
\text { trees }\end{array}$} \\
\hline & & 3.32 & \pm & 0.34 & & 4.39 & \pm & 0.43 & & 4.29 & \pm & 0.24 & \\
\hline \multirow{3}{*}{ BAI trend $\left(\mathrm{cm}^{2}\right.$ year $\left.{ }^{-2}\right)$} & $1991-2010$ & 3.46 & \pm & 0.34 & & 3.86 & \pm & 0.49 & & 3.80 & \pm & 0.26 & \\
\hline & $1971-1990$ & 0.12 & \pm & 0.04 & $\mathrm{~b}$ & 0.05 & \pm & 0.03 & $\mathrm{~b}$ & -0.08 & \pm & 0.02 & $\mathrm{a}$ \\
\hline & $1991-2010$ & -0.01 & \pm & 0.02 & & 0.01 & \pm & 0.03 & & 0.03 & \pm & 0.02 & \\
\hline \multirow{2}{*}{ Correlation of BAI series between trees } & 1971-1990 & 0.66 & \pm & 0.06 & & 0.73 & \pm & 0.04 & & 0.78 & \pm & 0.02 & \\
\hline & $1991-2010$ & 0.81 & \pm & 0.03 & & 0.82 & \pm & 0.02 & & 0.87 & \pm & 0.02 & \\
\hline \multirow[t]{2}{*}{ Correlation between BAI and mean minimum January temperatures } & 1971-1990 & 0.42 & \pm & 0.03 & & 0.46 & \pm & 0.03 & & 0.40 & \pm & 0.03 & \\
\hline & $1991-2010$ & 0.31 & \pm & 0.02 & $a b$ & 0.25 & \pm & 0.02 & $\mathrm{a}$ & 0.37 & \pm & 0.02 & b \\
\hline \multirow[t]{2}{*}{ Correlation between BAI and mean maximum July temperatures } & $1971-1990$ & -0.25 & \pm & 0.05 & $\mathrm{~b}$ & -0.38 & \pm & 0.05 & $\mathrm{~b}$ & -0.55 & \pm & 0.03 & $\mathrm{a}$ \\
\hline & $1991-2010$ & -0.43 & \pm & 0.03 & & -0.41 & \pm & 0.03 & & -0.46 & \pm & 0.02 & \\
\hline \multirow[t]{2}{*}{ Correlation between BAI and January to July overall water balance } & 1971-1990 & 0.42 & \pm & 0.04 & $\mathrm{a}$ & 0.57 & \pm & 0.04 & $\mathrm{~b}$ & 0.70 & \pm & 0.02 & $\mathrm{c}$ \\
\hline & $1991-2010$ & 0.65 & \pm & 0.02 & & 0.65 & \pm & 0.02 & & 0.67 & \pm & 0.01 & \\
\hline \multirow[t]{2}{*}{ Resin-duct production (No. year ${ }^{-1}$ ) } & $1971-1990$ & 2.99 & \pm & 0.34 & $\mathrm{~b}$ & 3.29 & \pm & 0.40 & $\mathrm{~b}$ & 1.92 & \pm & 0.25 & $\mathrm{a}$ \\
\hline & $1991-2010$ & 1.64 & \pm & 0.23 & $a b$ & 2.30 & \pm & 0.29 & $\mathrm{~b}$ & 1.40 & \pm & 0.18 & $\mathrm{a}$ \\
\hline \multirow[t]{2}{*}{ Resin-duct density (No. $\mathrm{mm}^{-2}$ ) } & $1971-1990$ & 0.58 & \pm & 0.06 & $\mathrm{~b}$ & 0.52 & \pm & 0.04 & $\mathrm{~b}$ & 0.37 & \pm & 0.03 & $\mathrm{a}$ \\
\hline & $1991-2010$ & 0.62 & \pm & 0.08 & $\mathrm{ab}$ & 0.70 & \pm & 0.06 & $\mathrm{~b}$ & 0.50 & \pm & 0.05 & $\mathrm{a}$ \\
\hline \multirow[t]{2}{*}{$\delta^{13} \mathrm{C}(\%)$} & 1971-1990 & -23.07 & \pm & 0.23 & & -22.80 & \pm & 0.21 & & -22.71 & \pm & 0.17 & \\
\hline & $1991-2010$ & -23.61 & \pm & 0.11 & & -23.46 & \pm & 0.11 & & -23.45 & \pm & 0.11 & \\
\hline \multirow[t]{2}{*}{$\Delta(\%)$} & 1971-1990 & 16.07 & \pm & 0.24 & & 15.79 & \pm & 0.21 & & 15.70 & \pm & 0.18 & \\
\hline & $1991-2010$ & 15.94 & \pm & 0.11 & & 15.78 & \pm & 0.11 & & 15.78 & \pm & 0.12 & \\
\hline \multirow[t]{2}{*}{ iWUE $\left(\mu \mathrm{mol} \mathrm{mol}{ }^{-1}\right)$} & $1971-1990$ & 101.98 & \pm & 2.26 & & 104.62 & \pm & 2.00 & & 105.43 & \pm & 1.67 & \\
\hline & $1991-2010$ & 113.07 & \pm & 1.12 & & 114.66 & \pm & 1.16 & & 114.78 & \pm & 1.22 & \\
\hline
\end{tabular}

Table 2. Data on basal-area increment (BAI, see No. trees in Table 1), carbon isotope discrimination and intrinsic water-use efficiency (iWUE, $n$ $=5$ per tree type); and growth sensitivity to climate in dead beetle-infested and non-infested Aleppo pines. The growth sensitivity was based on the correlation coefficients calculated between climatic variables and BAI. Values are computed for two periods (1971-1990 and 1991-2010). Different letters indicate significant differences between tree types based on ANOVAs and post hoc LSD tests. Comparisons of the resin-duct production and density were based on 10 trees per type and were calculated using Mann-Whitney tests. Values are means \pm SE. 
807

\begin{tabular}{|c|c|c|c|}
\hline Tree type & $\begin{array}{l}\text { No. } \\
\text { trees }\end{array}$ & Selected model & $W i$ \\
\hline $\begin{array}{l}\text { Dead Orthotomicus- } \\
\quad \text { infested trees }\end{array}$ & 32 & $\begin{array}{c}0.11 \text { P-PET12p + 0.33 P-PET1 + 0.02 P-PET4 + 0.01 P-PET6 + 0.03P-PET7 + } 0.24 \text { Tm1 + 0.06 Tm2-0.34Tm5 + } \\
0.14 \text { Tm8 + 0.03TM5 - 0.09 TM6 - 0.19 TM7 }\end{array}$ & 95.6 \\
\hline $\begin{array}{l}\text { Dead Tomicus-infested } \\
\text { trees }\end{array}$ & 28 & $\begin{array}{c}0.12 \text { P-PET12p + 0.41 P-PET1 + 0.03 P-PET4 + 0.02 P-PET6 + 0.04P-PET7 + 0.23 Tm1 + 0.16 Tm2-0.40Tm5 + } \\
\text { 0.27Tm8-0.06TM5 - 0.20 TM6 - 0.30 TM7 }\end{array}$ & 90.2 \\
\hline Living non-infested trees & 45 & $\begin{array}{c}0.51 \text { P-PET12p + 0.50P-PET1 + 0-02 P-PET4 + 0.02P-PET6 + 0.04P-PET7 + 0.31 Tm1 + 0.13Tm2 + 0.34Tm8- } \\
\text { 0.27TM5 - 0.19TM6 - 0.32TM7 }\end{array}$ & 72.9 \\
\hline
\end{tabular}

Table 3. Best-fitted linear mixed-effects models of Aleppo pine basal-area increment (BAI) as a function of monthly climatic variables. Abbreviations: P, precipitation; P-PET, water balance; Tm, mean minimum temperatures; TM, mean maximum temperature; Wi, relative probability that the model is the best model for the observed data. Months are abbreviated by their corresponding numbers and they correspond to the year prior to tree-ring formation when followed by " $p$ ". 


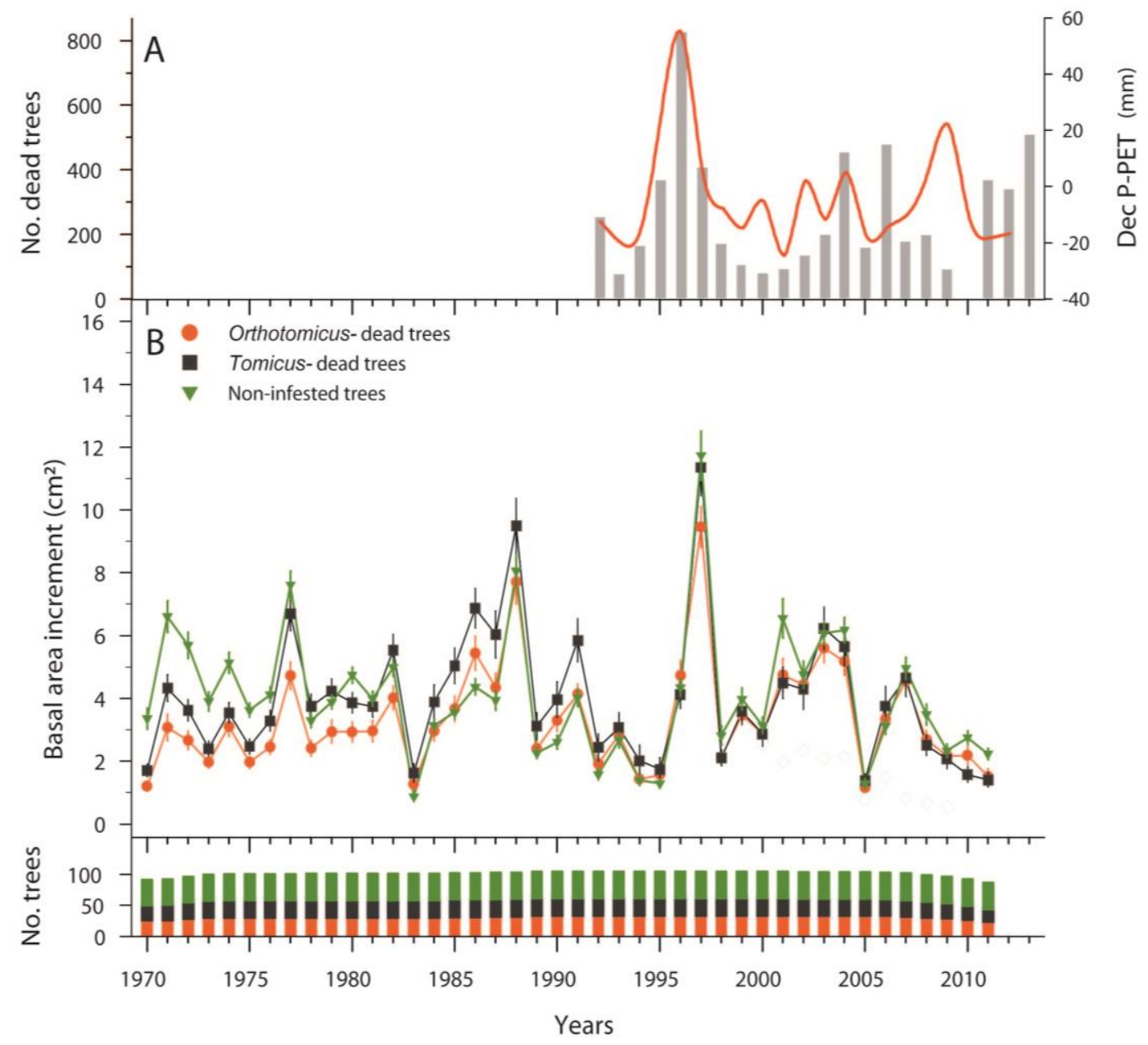

808

809

Figure 1

810 


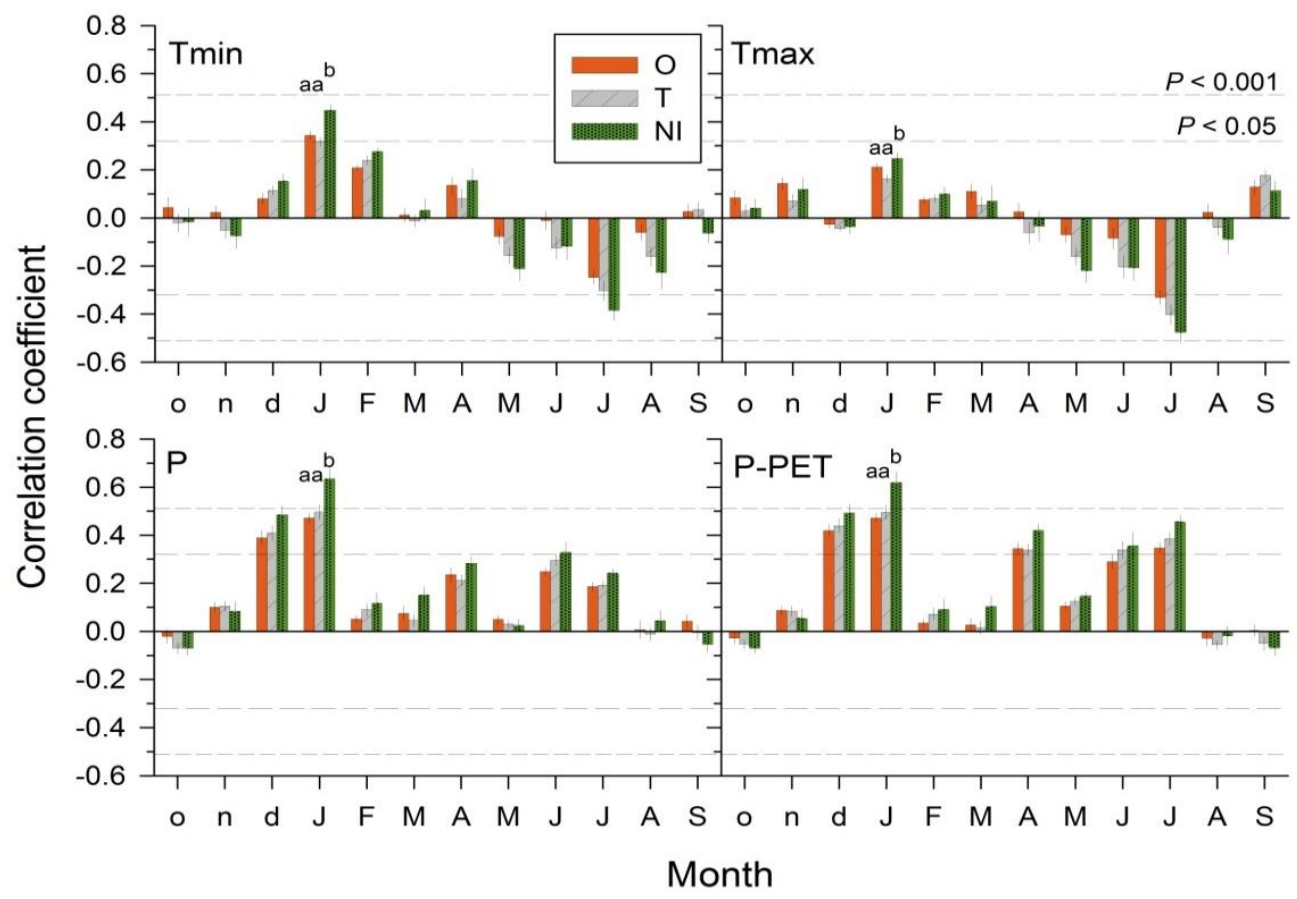

811

$812 \quad$ Figure 2

813 


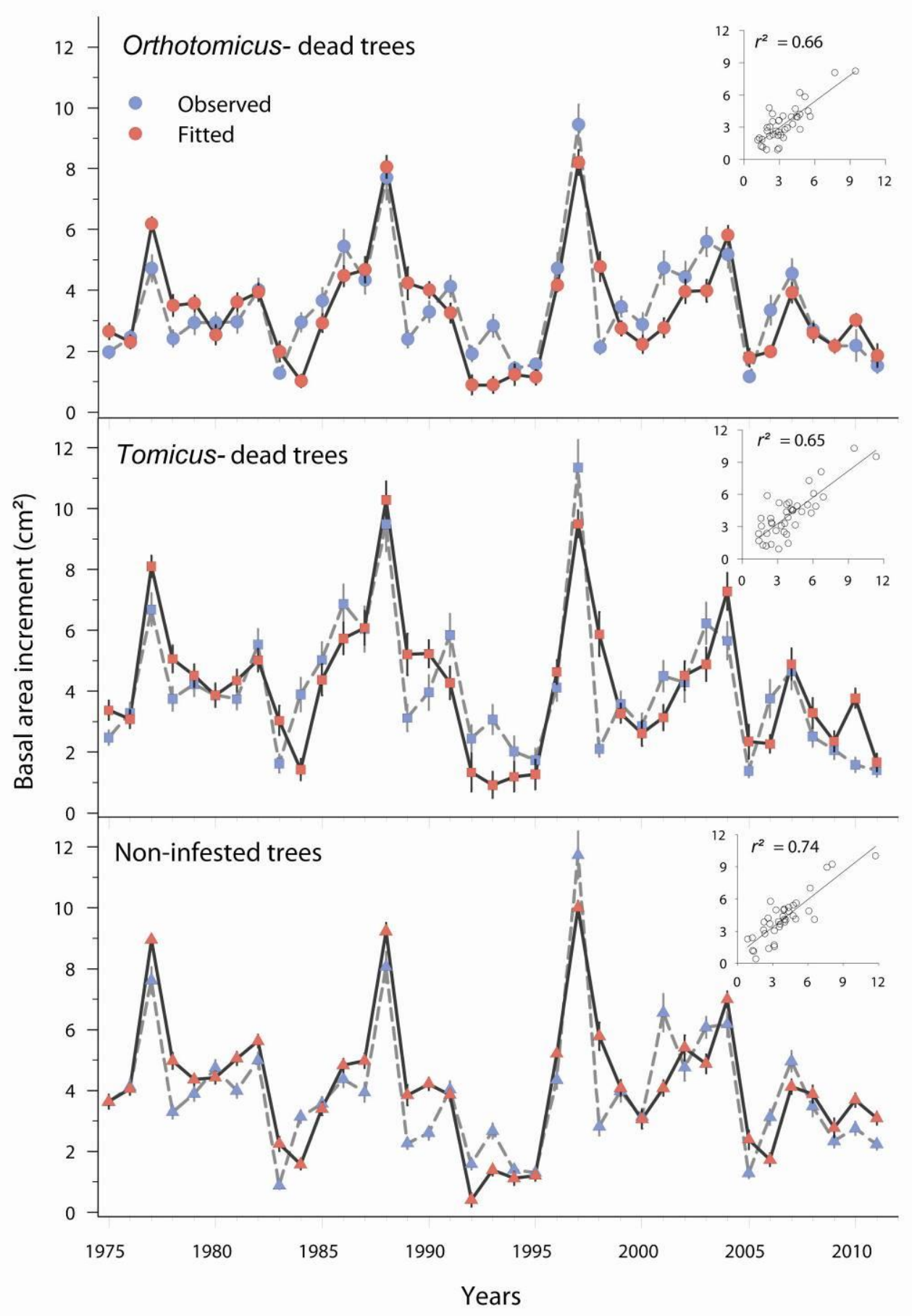

814

815 Figure 3

816 

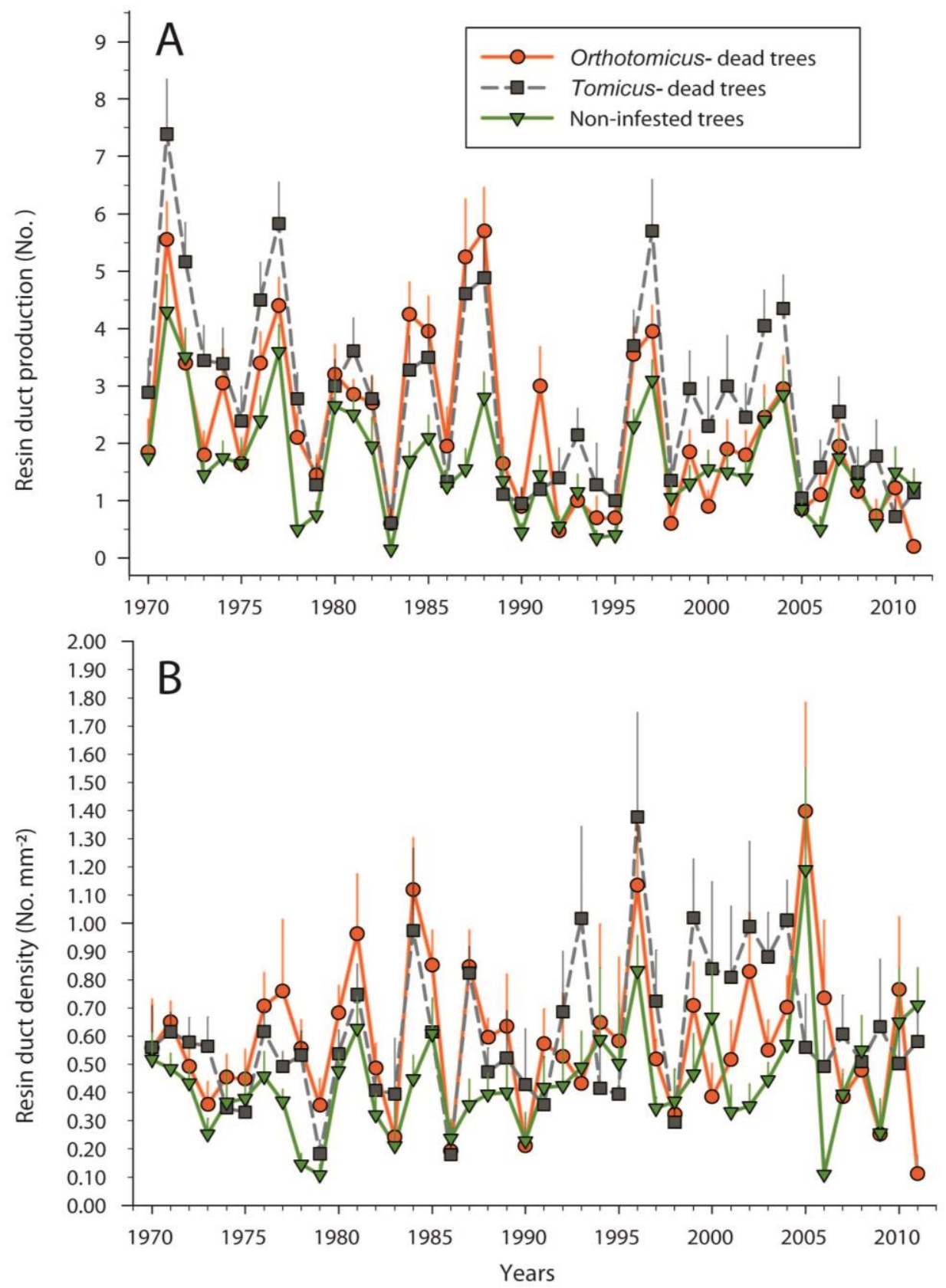

817

$818 \quad$ Figure 4

819 

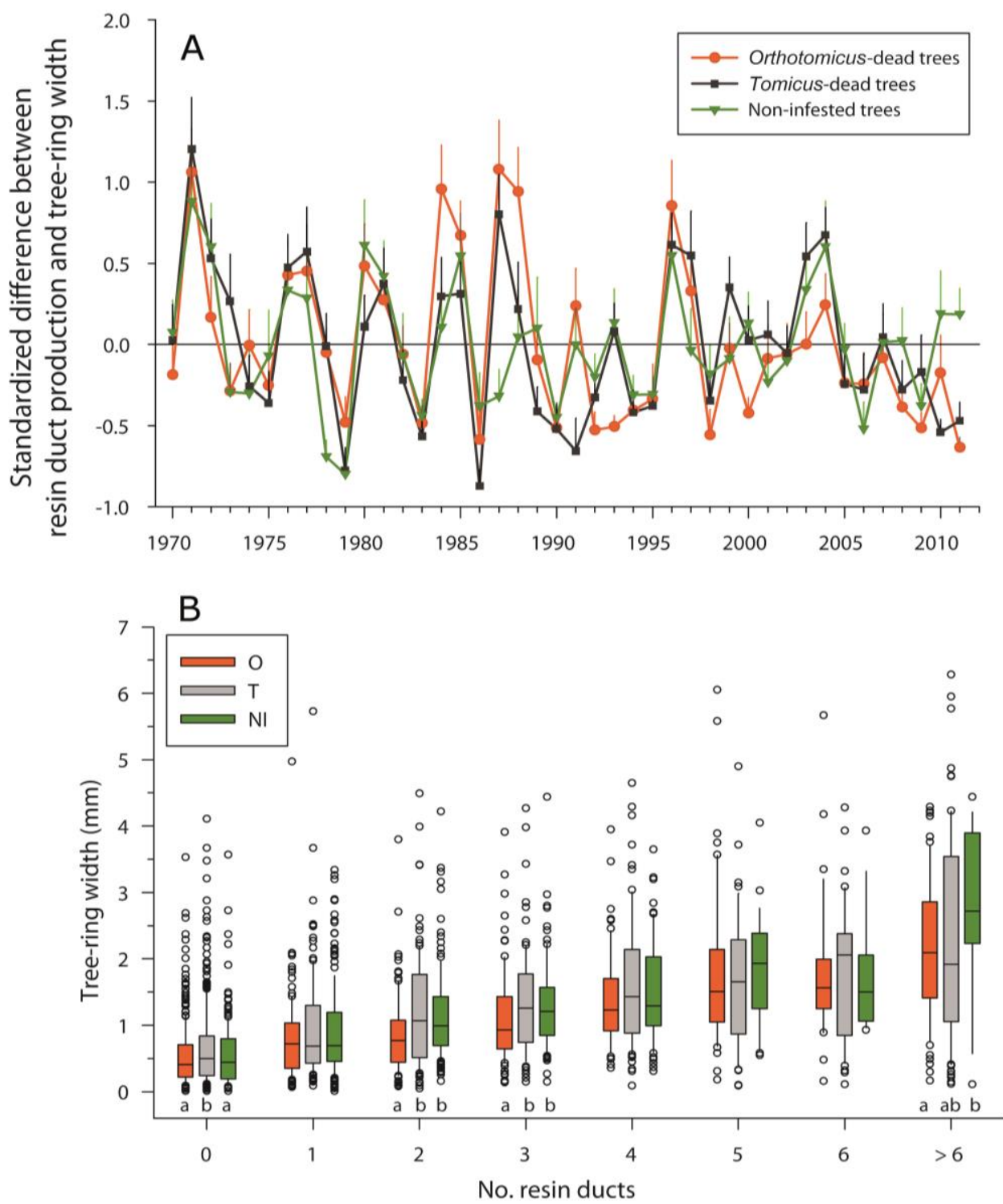

820

$821 \quad$ Figure 5

822 


\section{Supporting Information}

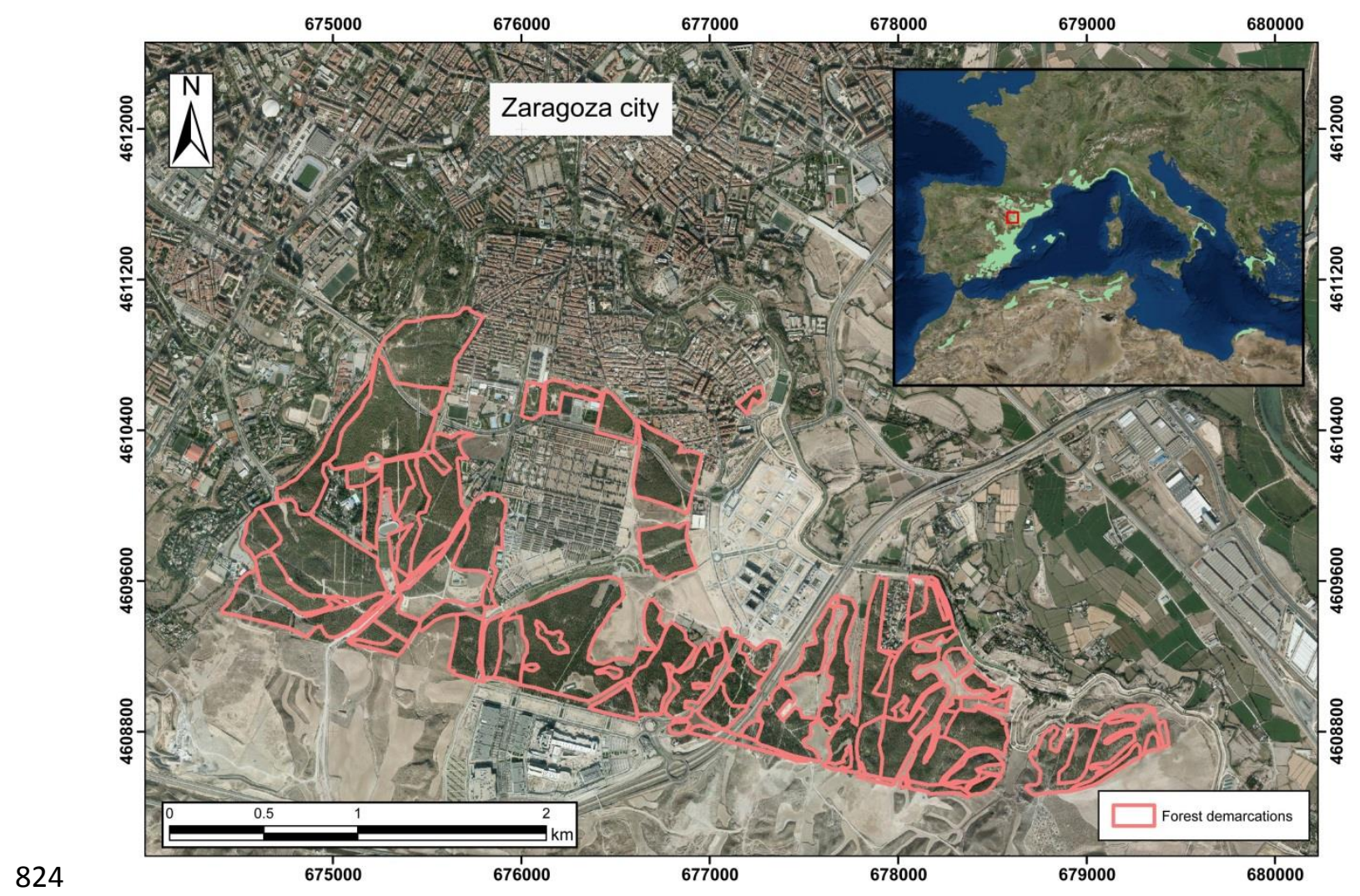

825 Figure S1. Geographical situation of the study Aleppo pine plantations in Zaragoza 826 (north-Eastern Spain). The red lines show the forest demarcations. The upper right inset 827 shows the Aleppo pine distribution in W. Europe (green areas), and the situation of the 828 study area (red square). 
A

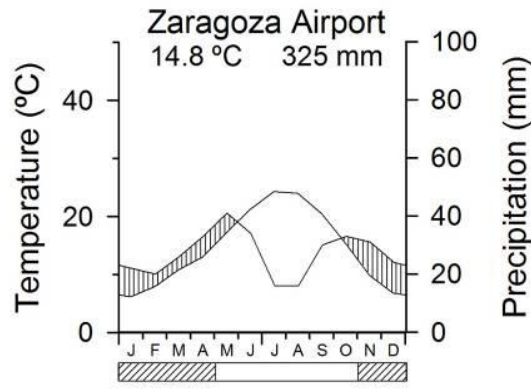

B

C

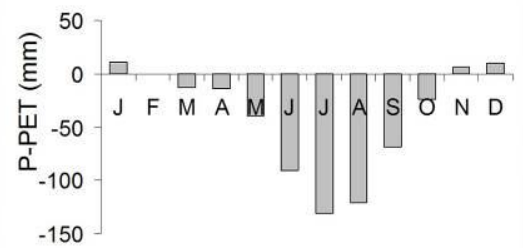

Month

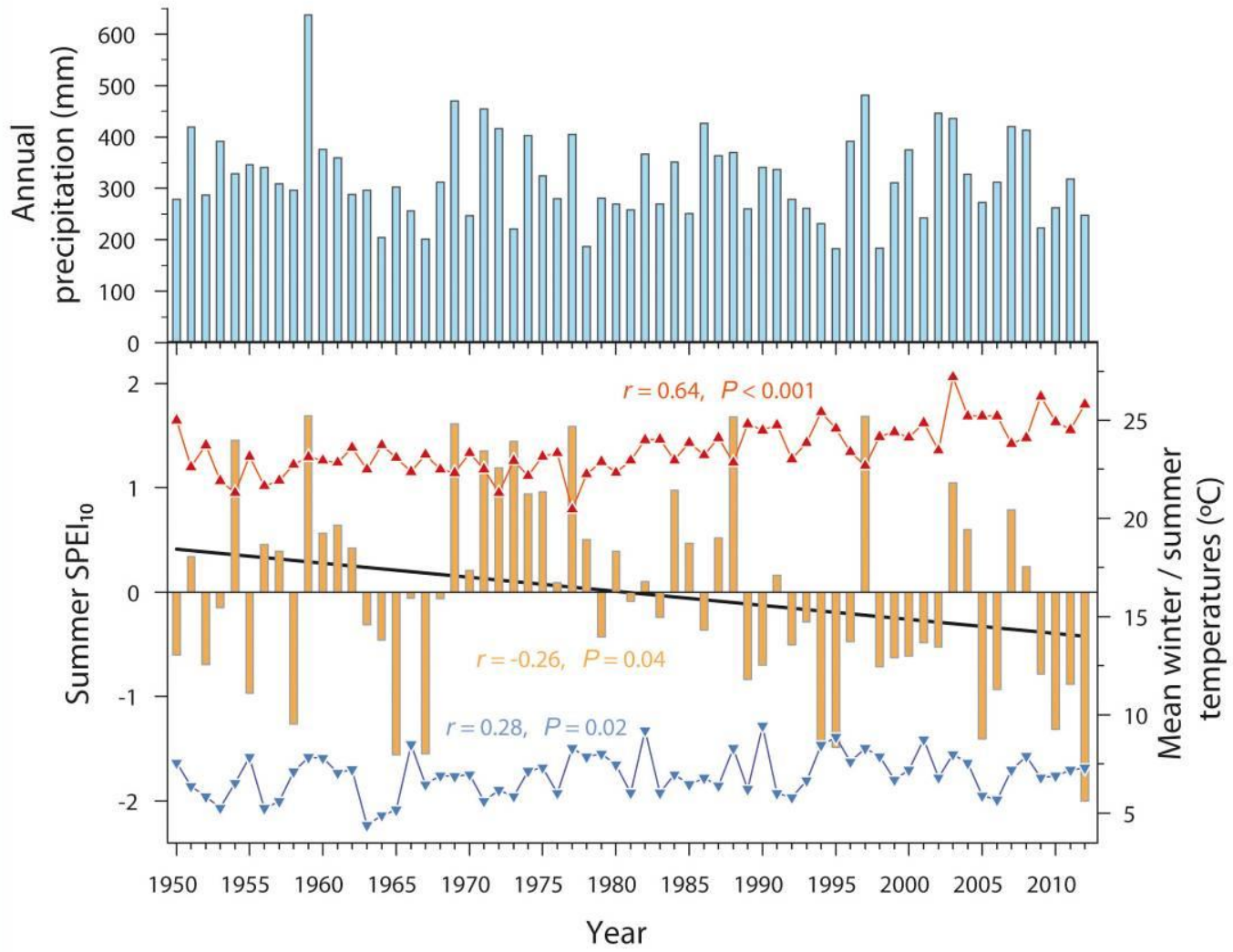

829

830 Figure S2. A) Climatic diagram of the study area (Zaragoza airport meteorological station) B)

831 mean water balance. C) Climatic trends observed between 1950 and 2012. The orange bars

832 indicate the summer (June to August) 10-month Standardized Precipitation-Evaporation Index

833 (SPEI) values (positive and negative values indicate wet and dry conditions, respectively). The

834 blue bars show the precipitation, the red and blue lines show the mean winter and summer

835 temperatures. Numbers indicate corresponding trends $(r)$ and related probability levels $(P)$. 


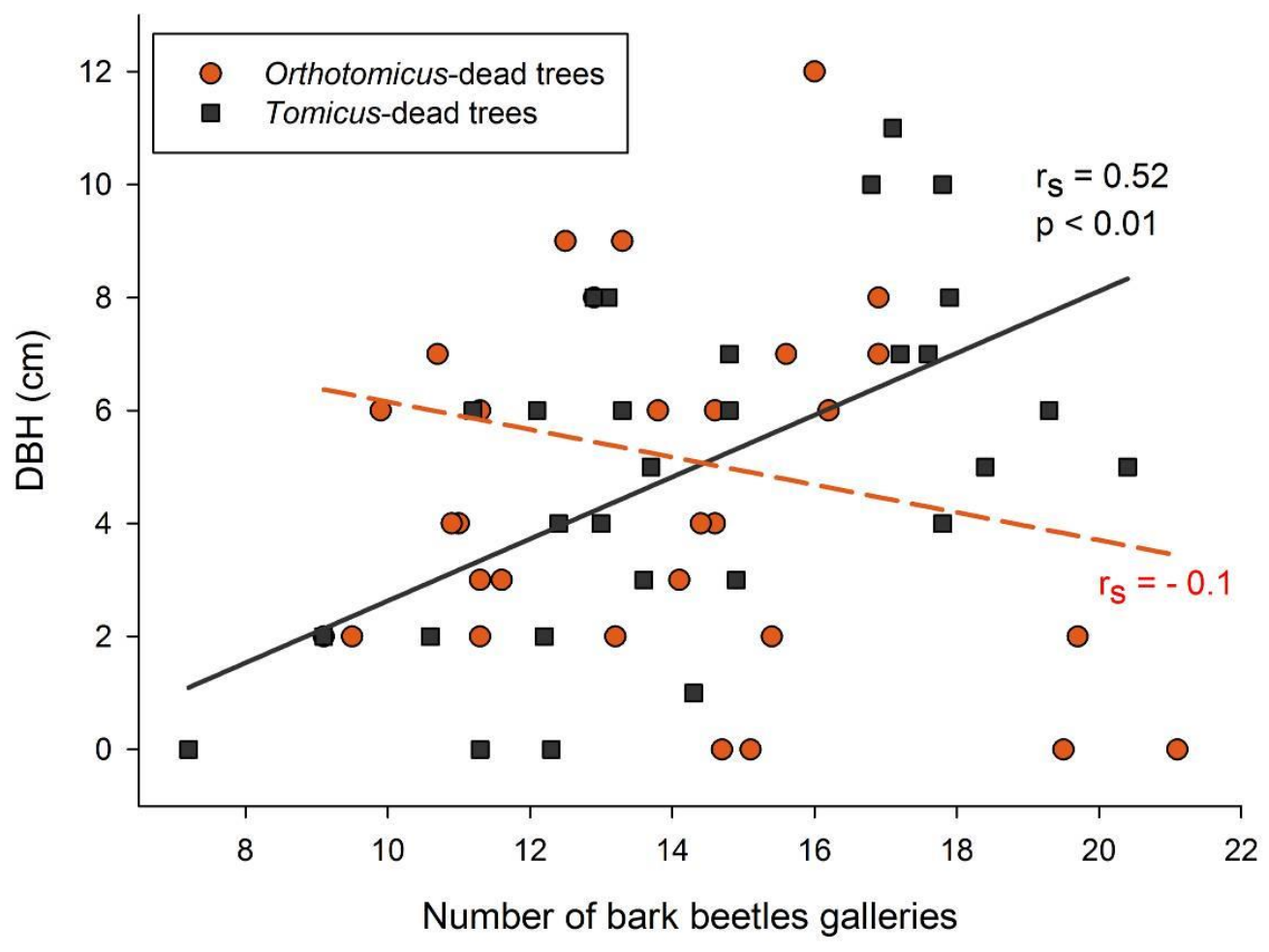

836

837 Figure S3. Relationships between tree-size (DBH) and the number of bark beetle galleries for 838 two bark beetle species considering dead trees infested either by (orange circles) or by Tomicus 839 (black squares). The discontinuous (Orthotomicus) and continuous (Tomicus) lines indicate the trends and related Spearman correlation coefficients $\left(r_{s}\right)$ are shown.

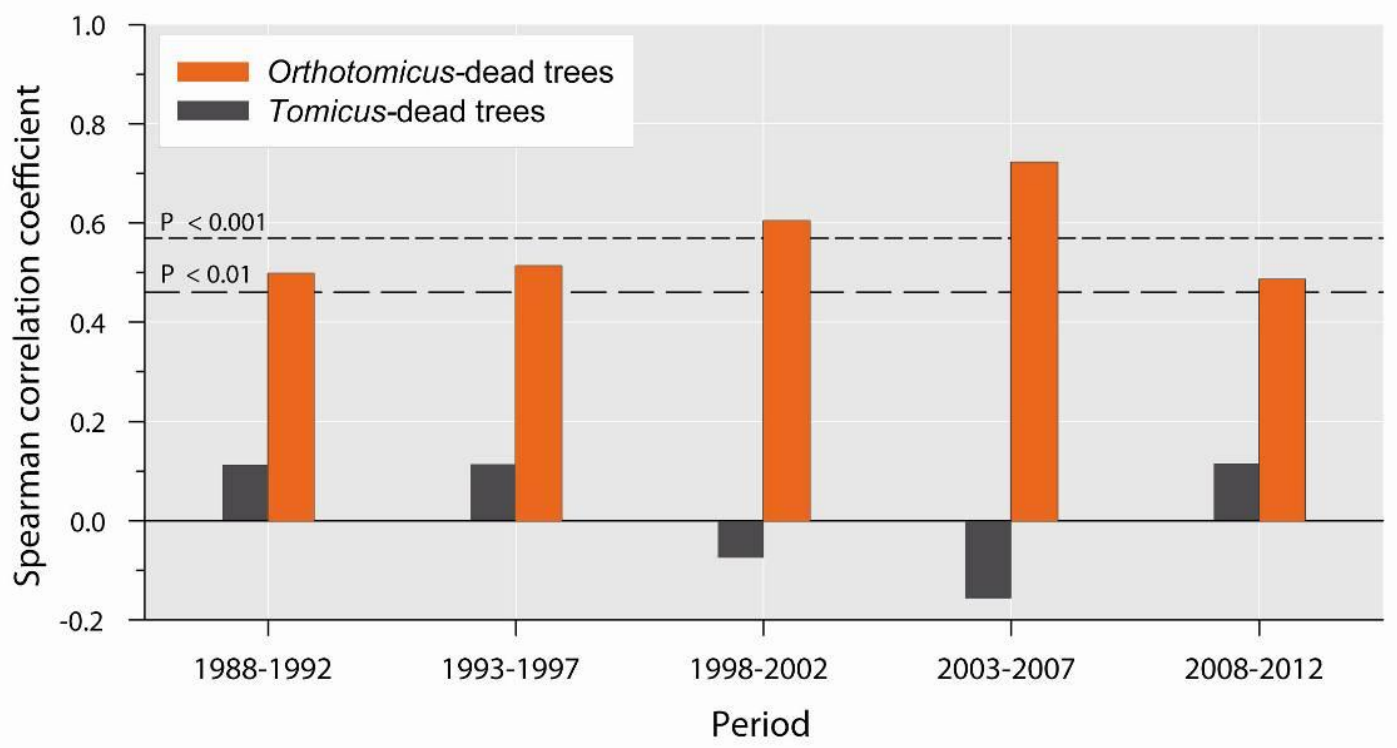

Figure S4. Spearman correlation coefficients calculated by relating the amount of bark beetles 843 galleries engraved in the sapwood and growth data (tree-ring widths) averaged in different 5844 year periods considering either dead trees infested by Orthotomicus (orange bars) or by Tomicus 845 (black bars). 

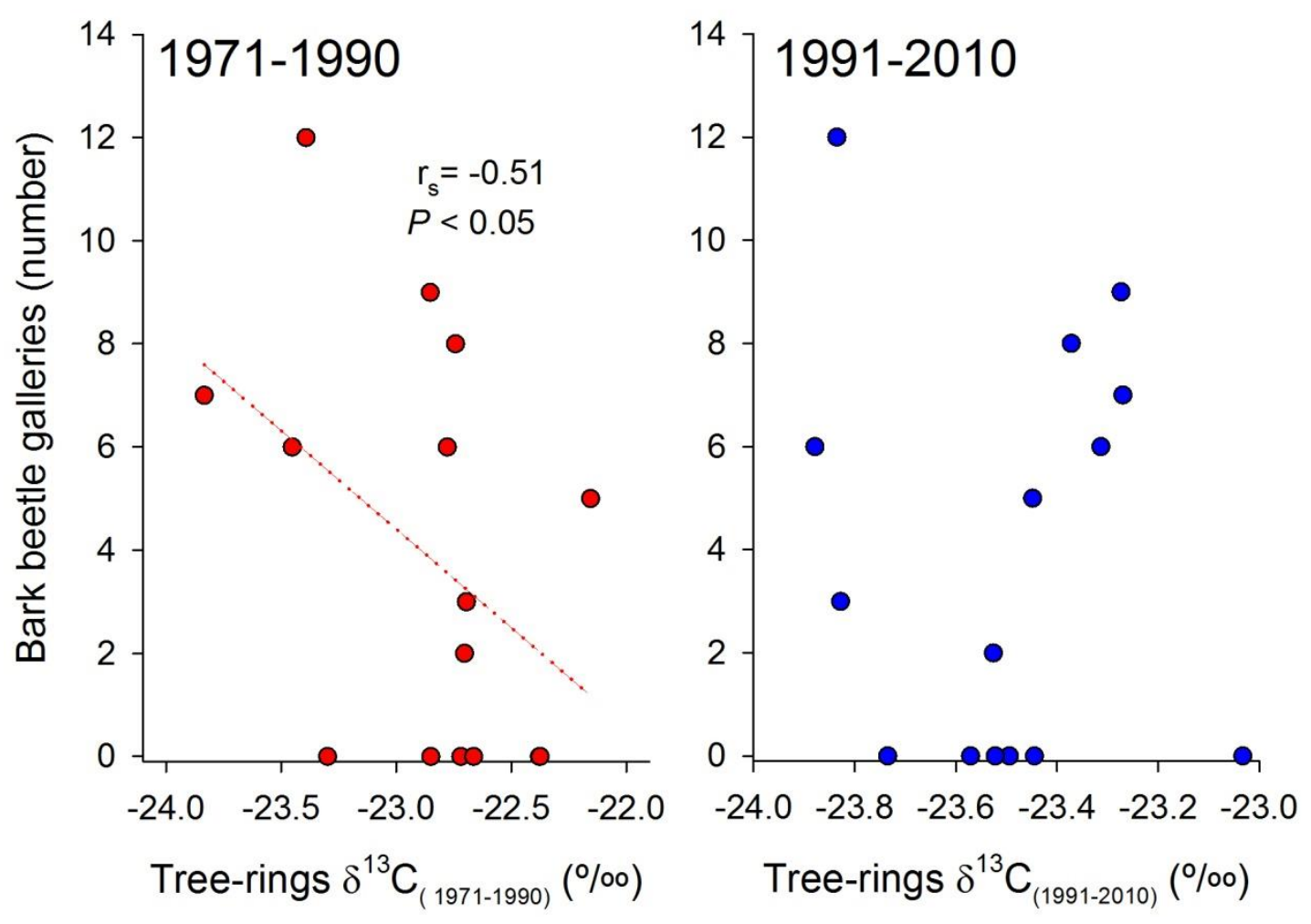

847 Figure S5. Relationships between the number of bark beetle galleries observed in trees infested 848 by bark beetles (Orthotomicus and Tomicus) and the tree-ring carbon isotope discrimination 849 values for two periods (1971-1990 and 1991-2010). Rest of explanations is as in Fig. S3. 
Table S1 Best-fitted linear mixed-effects models of Aleppo pine basal area increment (BAI) as a function of climatic variables and considering three types of trees (Orthotomicus-dead trees, Tomicus-dead trees and living non-infested trees). A null model using BAI as a constant is also included. Abbreviations: $k$, number of parameters included in the model; AICc, Akaike information criterion corrected for small samples; PPET12p, difference between precipitation and potential evapotranspiration of December of the previous year; P-PET1, difference between precipitation and potential evapotranspiration of January; P-PET4, difference between precipitation and potential evapotranspiration of April; PPET6, difference between precipitation and potential evapotranspiration of June; P-PET7, difference between precipitation and potential evapotranspiration of July; Tm1, January minimum temperature; Tm2, February minimum temperature; Tm5, May minimum temperature; Tm8, August minimum temperature; TM5, May maximum temperature; TM6, June maximum temperature; TM7, July maximum temperature; Wi, relative probability that model $i$ is the best model (shown in bold) for the observed data; $\Delta i$, difference in AICc with respect to the best model.

\begin{tabular}{|c|c|c|c|c|c|c|c|c|c|c|}
\hline \multirow{3}{*}{ Variables entering best-fitted models } & \multicolumn{10}{|c|}{ Tree type } \\
\hline & \multirow{2}{*}{$k$} & \multicolumn{3}{|c|}{ Orthotomicus-dead trees } & \multicolumn{3}{|c|}{ Tomicus-dead trees } & \multicolumn{3}{|c|}{ Non-infested trees } \\
\hline & & $\mathrm{AICc}$ & $\Delta i$ & $W i$ & $\mathrm{AICc}$ & $\Delta i$ & $W i$ & $\mathrm{AICc}$ & $\Delta i$ & $W i$ \\
\hline $\begin{array}{c}\text { P-PET12p, P-PET1, P-PET4, P-PET6, P-PET7, Tm1, Tm2-, } \\
\text { Tm5, Tm8, TM5, TM6, TM7 }\end{array}$ & 14 & 5335.6 & $\mathbf{0}$ & 95.60 & 5317.1 & $\mathbf{0}$ & 90.21 & 8046.4 & 2.0 & 27.09 \\
\hline $\begin{array}{c}\text { P-PET12p, P-PET1, P-PET4, P-PET6, P-PET7, Tm1, Tm2-, } \\
\text { Tm8, TM5, TM6, TM7 }\end{array}$ & 13 & 5342.2 & 6.6 & 0.04 & 5321.6 & 4.5 & 9.58 & 8044.4 & $\mathbf{0}$ & 72.91 \\
\hline $\begin{array}{c}\text { P-PET12p, P-PET1, P-PET4, P-PET6, P-PET7, Tm1, Tm2, } \\
\text { TM7 }\end{array}$ & 10 & 5355.4 & 19.8 & 0 & 5353.1 & 35.9 & 0 & 8118.6 & 74.2 & 0 \\
\hline P-PET12p, P-PET1, P-PET4, P-PET6, P-PET7, Tm1 & 8 & 5364.8 & 29.2 & 0 & 5368.8 & 51.7 & 0 & 8118.5 & 74.0 & 0 \\
\hline Null model & 2 & 6209.4 & 873.8 & - & 6092.8 & 775.6 & - & 9414.8 & 1370.3 & - \\
\hline
\end{tabular}

